\title{
Perspectives on the Barriers to and Needs of Teachers' Professional Development in the Philippines during COVID-19
}

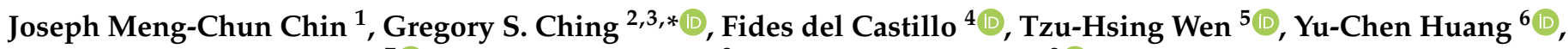 \\ Clarence Darro del Castillo ${ }^{7} \mathbb{C}^{\circ}$, Jenny Lynn Gungon ${ }^{8}$ and Sheilla M. Trajera ${ }^{9}$
}

check for updates

Citation: Chin, J.M.-C.; Ching, G.S.; del Castillo, F.; Wen, T.-H.; Huang, Y.-C.; del Castillo, C.D.; Gungon, J.L.; Trajera, S.M. Perspectives on the Barriers to and Needs of Teachers' Professional Development in the Philippines during COVID-19. Sustainability 2022, 14, 470. https:// doi.org/10.3390/su14010470

Academic Editors: José Antonio Marín-Marín, Santiago Alonso-García and Fernando José Sadio Ramos

Received: 25 November 2021 Accepted: 30 December 2021 Published: 2 January 2022

Publisher's Note: MDPI stays neutral with regard to jurisdictional claims in published maps and institutional affiliations.

Copyright: (c) 2022 by the authors. Licensee MDPI, Basel, Switzerland. This article is an open access article distributed under the terms and conditions of the Creative Commons Attribution (CC BY) license (https:/ / creativecommons.org/licenses/by/ $4.0 /)$.
1 Graduate Institute of Educational Administration and Policy, National ChengChi University, Taipei City 116011, Taiwan; mcchin@nccu.edu.tw

2 Graduate Institute of Educational Leadership and Development, Fu Jen Catholic University, New Taipei City 24205, Taiwan

3 Research and Development Center for Physical Education, Health, and Information Technology, Fu Jen Catholic University, New Taipei City 24205, Taiwan

4 Theology and Religious Education Department, De La Salle University, Manila 1004, Philippines; fides.delcastillo@dlsu.edu.ph

5 Office of Teacher Education and Careers Services, National Taichung University of Education, Taichung City 40306, Taiwan; kksunub@gmail.com

6 Bachelor's Program in Educational Leadership and Technology Development, Fu Jen Catholic University, New Taipei City 24205, Taiwan; piperginny@gmail.com

7 Administration Office, Lumina Foundation for Integral Human Development, Calamba City 4027, Philippines; cdbdelcastillo@gmail.com

8 Malabon National High School, Malabon City 1470, Philippines; jennylynn.gungon@deped.gov.ph

9 Center for Linkages and International Affairs, BSN, MN, and PhD Programs in Nursing, University of St. La Salle, Bacolod City 6100, Philippines; s.trajera@usls.edu.ph

* Correspondence: 094478@mail.fju.edu.tw

\begin{abstract}
Due to COVID-19, remote or distance education has become the norm in the Philippines. Yet even in its second year, remote teaching and learning still face ongoing challenges, as does the need for teachers' professional development. This paper describes a study that examined teachers' perspectives on barriers and needs in professional development. The study involved 174 teachers who were teaching online courses in the National Capital Region. The participants completed a survey detailing their professional development frequency, perspectives, barriers, and needs, while eight teachers agreed to participate in a follow-up interview. Results from hierarchical multiple regression analysis have shown that teachers' pedagogical and information technology skills requirements are influenced primarily by their prior professional development experiences and their need to apply active learning and innovative teaching ideas. Qualitative analyses indicate that teachers' professional development needs are mostly focused on skills related to online teaching, information technology literacy, and conducting research. In addition, data indicated that barriers to professional development were primarily caused by financial and time constraints and a lack of teacher motivation and logistical support. In summary, for remote education to be sustainable, teachers need ongoing professional development as well as adequate logistical support.
\end{abstract}

Keywords: teacher professional development; information technology literacy; remote teaching and learning; Philippines; COVID-19

\section{Introduction}

Schools have been closed in the Philippines since the outbreak of the COVID-19 pandemic $[1,2]$. In the second year of the learning continuity plan, remote or distance learning has already become the new normal in the Philippines [3]. However, remote education has left many Filipino parents questioning whether or not their children are actually learning [4-6]. Remote education in the Philippines consists of a variety of modalities, including 
online instruction (online classes), blended learning (a combination of synchronous and asynchronous learning), streaming media (including radio and television), and printed lesson materials [7,8]. Recent surveys have noted that apart from the lack of access to an effective learning platform and the insufficient internet bandwidth [9-11], teacher training is also badly needed [12,13]. In December 2021, the Department of Education began allowing a limited number of schools to offer face-to-face classes [14-16]. Despite the current Omicron variant, schools are expected to reopen gradually in $2022[17,18]$. With the uncertainty of the pandemic still looming, teachers can essentially continue to prepare and equip themselves with the skills necessary to deal with it.

In the context of online instruction during the COVID-19 pandemic, in-service teacher training or teacher professional development (TPD) with regard to the use of technology and student counseling is absolutely necessary in order to meet the academic challenges and the socio-emotional demands of teachers and students alike [19-22]. Since teacher development is an ongoing process $[13,23,24]$, early TPD initiatives have focused on technological advances that support pedagogy, such as multimedia and other information technology-related teaching innovations [25]. Recent TPD activities have increasingly focused on maintaining the teaching career, which is particularly relevant in the current situation of the COVID-19 pandemic $[26,27]$.

An overarching conceptual framework for the TPD facilitates the acquisition of knowledge for in-service teachers in various ways. Postholm [28] proposed that, in addition to formal continuing education (e.g., masters or doctoral degrees), teachers can best develop their skills through various activities within their school. Moreover, it is also important to note that these learning activities or professional development activities within the school should be content-focused, active learning (the process of observing expert teachers), coherence (consistent with prior knowledge), duration (training spread over a period of time), and have the participation or cooperation of their peers (co-teachers) [29]. Importantly, this additional knowledge gained through the various TPDs will enable teachers to apply it to their classrooms. In turn, this will enhance the overall teaching and learning experience.

Based on the premise that quality education is derived from the competence of teachers [30], the TPD, therefore, plays a crucial role in this achievement [31]. As a consequence, it follows that quality education is an essential factor in achieving the goals of education for sustainable development (ESD) [32]. Importantly, quality education brings value and benefit to the achievement of the United Nations Education, Scientific and Cultural Organization Goals for Sustainable Development (SDGs), which requires teachers to continually educate themselves [33,34]. Similarly, the objective of ESD also entails the need to train teachers to understand the educational implications of sustainable development [35]. Furthermore, teacher training for ESD could also be best achieved through the use of online learning or e-learning approaches in a way that promotes both interest and participation [36]. However, studies have found that the online approach for ESD has both advantages and disadvantages [37]. It is found that although e-learning approaches provide easy access to many types of information, this may not be a viable solution for the development of specific skills, identity, and confidence [38]. In essence, the importance of professional development, especially in the education sector, cannot be overstated as it is fundamental to achieving quality education and subsequently reaching the SDGs.

Realizing the urgent need for understanding the teaching and learning process, the Organization for Economic Cooperation and Development (OECD) spearheaded the Teaching and Learning International Survey (TALIS); a large-scale survey of teachers, school leaders, and their learning environments, wherein a section is focused on collecting information with regards to the status of TPD [39-41]. By analyzing the 2016 and 2018 TALIS surveys, the TPD findings in relation to the needs of teachers are better understood, thereby improving future planning and design of training activities $[42,43]$. Since the Philippines is not one of the countries in which the TALIS data is collected, reference to the surveys is limited to identifying domestic needs for TPD improvements [44,45]. Despite this, TPD is a significant trend in the Philippines. 
For more than a decade and until recently, TPD in the Philippines has focused on improving science and mathematics instruction [46,47]. As part of the TPD initiative, pedagogical innovations for curriculum development were introduced to improve student performance in the fields of science and mathematics [48-50]. In addition, some scholars have explored the use of Massive Open Online Courses (MOOCs), which are effective in replacing face-to-face events to increase participation and spread of TPD [44,51]. In recent years, TPD has also become popular for promoting faculty collaborations and classroombased research (or participatory action researches) [52,53]. Importantly, TPD can also be used to cultivate a culture of lifelong learning [54]. However, with each school year, teachers have to adapt their pedagogical approaches as new learning standards and competencies are adopted. As such, TPD can be seen as a way to support teachers and lead them to sustainable careers.

Against this background, this paper tries to better understand the TPD in relation to the TALIS approaches. By using both quantitative and qualitative data, a comprehensive picture of the TPD in the Philippines can be derived. Specific objectives include :

- Determine the frequency and preferences of TPD;

- Identify the barriers to and needs of TPD; and

- Determine the relationship between TPD needs and preferences.

\section{Materials and Methods}

\subsection{Research Design and Procedure}

For the purpose of enriching the data presentation [55], both quantitative and qualitative data are collected and analyzed [56]. This study uses a voluntary response sampling method, in which participants voluntarily decide to participate in the study [57]. The inclusion criteria called for teachers who have had online teaching experience in the last two semesters. For the quantitative data, several TALIS TPD components were collected, such as: TPD frequency, TPD preferences, barriers to TPD, and a modified TPD needs survey. Qualitative data refers to two open-ended questions about TPD barriers and needs included in the survey, as well as one-on-one interviews with eight volunteer teachers. The data was collected from September to November 2021 with the help of several teachers' associations and school administrators. Importantly, the data is collected within an educational setting (after a regular online meeting or educational workshop) as part of an activity or feedback with learning opportunities and policy improvements. Using an online survey, voluntary participants can withdraw at any time without any consequences. In addition, the purpose of the study and the use of the data collected were also explained. In the course of the data collection, volunteers were also called for the following individual interviews. Initially, eleven teachers volunteered to participate. However, only eight teachers took part in the actual interviews.

The individual interview protocols are as follows: Each interview was conducted via Google Meet at a time convenient for the participants. Each interview lasted 20 to $30 \mathrm{~min}$. The purpose of the interview was to allow the participants to share their opinions and comments on the obstacles and needs of TPD. Before the interview began, the aim and purpose of the study was explained, and verbal consent was obtained. Initial guiding questions were "what is your opinion regarding the professional development at your school", "what topics do you think are needed", and "what do you think are some of the challenges to the implementation of professional development". Participants' comments were recorded and transcribed verbatim [58]. A copy of the transcription was then sent to the participants for review and approval.

\subsection{Measures}

Background variables of the participants collected are gender, age, teaching experience (in years), graduate degree, school type (public or private), university level, administrative work experience (or duties), and Science, Technology, Engineering, and Mathematics (STEM) related subject expertise. These variables were selected based on their perceived 
impact on TPD. As mentioned earlier, TPD in the Philippines is heavily linked to science and mathematics $[46,50]$. Thus, STEM teachers might have a different perspective on TPD barriers and needs. TPD also shows some significant differences between public and private institutions in terms of financial and logistical support [59]. In addition, early TALIS reports also identified the influence of other background variables on the incidence and preferences related to TPD [60].

For the TPD frequency, adapted from TALIS, these are the various activities within and beyond the classroom, as well as other professional practices such as collaboration and participation in school decisions that foster professional development $[29,39]$. TPD frequency consisted of eight items such as "teach jointly as a team in the same class" and "attend team conferences, seminars, or workshops". Data were collected using a sixpoint Likert [61] type scale perceived frequency on the different professional development activities, wherein $1=$ never, $2=$ once a year, $3=2$ to 4 times a year, $4=5$ to 10 times a year, $5=1$ to 3 times a month, and $6=$ once a week or more. Cronbach [62] alpha reliability of the TPD frequency was computed at 0.92 , signifying good internal consistency [63].

For the TPD preferences, adapted from TALIS, these are different insights into the types of training content that improve teaching [29,39]. TPD preferences consisted of twelve items such as "it built on my prior knowledge", "it provided opportunities for active learning", and "it focused on innovation in my teaching". Data were collected using a four-point Likert type scale perceived level of agreement on the different TPD preferences, wherein 1 = strongly disagree to $4=$ strongly agree. Cronbach alpha reliability of the TPD preferences was computed at 0.96 , signifying very good internal consistency.

The TPD barriers, also adapted from TALIS, are the various teachers' perspectives on the barriers to educational development [39]. TPD barriers consisted of seven items such as "professional development is too expensive" and "there are no incentives for participating in professional development". Data were collected using a four-point Likert type scale perceived level of agreement on the different TPD barriers, wherein $1=$ strongly disagree to $4=$ strongly agree. Cronbach alpha reliability of the TPD barriers was computed at 0.92 , signifying good internal consistency.

Lastly, the TPD needs included various seemingly unmet professional development priorities of teachers based on TALIS and several educational technology skills required during COVID-19 [39,64]. The TPD needs consisted of 21 items such as "knowledge of the curriculum", "analysis and use of student assessments", "software for classroom management or learning management systems", and "digital tools to identify and analyze the needs and characteristics of students". Data were collected using a four-point Likert type scale perceived level of agreement on the different TPD needs, wherein $1=$ strongly disagree to $4=$ strongly agree. Cronbach alpha reliability of the TPD needs was computed at 0.98 , signifying very good internal consistency.

\subsection{Data Analysis}

For the quantitative data, the expectation maximization algorithm was used to impute data missing from less than 5 percent of the total dataset $[65,66]$. As part of the analysis of the data distribution, descriptive statistics such as mean and standard deviation (SD) and Cronbach [62] alpha internal consistencies were calculated using SPSS version 20 (IBM, Armonk, NY, USA) borrowed from the university. The intercorrelations between the participants' age, teaching experience, TPD frequency, needs, and barriers, the initial exploratory factor analyses of the TPD needs, group comparison with the various background demographics using independent samples t-tests, and concluding regression analyses were all conducted using SPSS. Confirmatory factor analysis of the TPD needs was performed using structural equation modeling with the assistance of SPSS AMOS version 26 (IBM, Armonk, NY, USA) according to a lease with Hearne software (Melbourne, Australia, https: / / www.hearne.software/Home, accessed on 1 October 2021).

Construct validity and reliability of the TPD needs variables were assessed by computing for the composite reliability (CR), convergent validity (average variance extracted, AVE), 
discriminant validity (DV; computed by taking the square root of AVE), and heterotraitmonotrait ratio of correlations (HTMT) [67-70]. Various criteria were used in the evaluation of construct validity and reliability. Acceptable values for CR should be above 0.50 [71], while a value of more than 0.70 is much better [72]. AVE should be above 0.50, DV should be greater than the variable's interconstruct correlations [68], while HTMT should be below 0.90 [73]. In determining the model fits for the confirmatory factor analysis, several criteria were used: Standardized Root Mean Square Residual (SRMR; values should be less than 0.08 to indicate a good fit), significant Chi-square, Chi-square divided by degrees of freedom (CMIN/df; ratio must fall between 2 and 5 to indicate a reasonable fit), Root Mean-Square Error of Approximation (RMSEA; values should be less than 0.08 to indicate a good fit) including $90 \%$ confidence interval $(90 \% \mathrm{CI})$, and Goodness of Fit Index (GFI), Tucker-Lewis Index (TLI), Comparative Fit Index (CFI), ideally, all of these values should be greater than 0.90 to show good fit [72,74]. Lastly, hierarchical multiple regressions were used to determine the predictors for the TPD needs variables [75,76]. More specifically, the association of TPD preferences with the TPD needs.

The qualitative data included two open-ended questions that were included in the survey, as well as one-on-one interviews with eight volunteer teachers. Using Voyant Tools, the responses were transcribed and analyzed for trends and relationships [77]. Keyword clouds (also called tag clouds) were used to visualize the most frequently used words by the respondents in descending order of frequency [78]. Additionally, bubblelines and word trends were provided to help visualize the frequency and distribution of the five main keywords [79]. Lastly, close proximity links or collocates of the five main keywords are shown in order to visualize the underlying relationship within texts $[80,81]$.

\section{Results}

\subsection{Participants}

Participants of the study are 174 volunteer teachers who have experienced online instruction from the National Capital Region in the last two semesters. Within the region, there is a total of 75,058 teachers [82]. Voluntary sampling was used, where participants voluntarily chose to participate in the study. The average age of the participants is 38 years, which means a relatively young group of teachers. The average work experience is 12 years, which means a moderately experienced group of teachers. Table 1 show that among the participants, 107 (or 61\%) are female, and 67 (or 39\%) are male. In total, 144 (or 83\%) are graduate degree holders, 133 (or 76\%) are working in public institutions (governmentowned schools), 58 (or 44\%) are university faculty, 52 (or 30\%) have administrative-related duties, and 85 (or 49\%) are teachers who taught in STEM-related subjects.

Table 1. Demographic profile of the participants.

\begin{tabular}{cccc}
\hline Demographics & Classification & $\boldsymbol{n}$ & $\mathbf{\%}$ \\
\hline Gender & Female & 107 & 61 \\
& Male & 67 & 39 \\
\hline Graduate degree holder & Yes & 144 & 83 \\
& No & 30 & 17 \\
\hline School type & Public & 133 & 76 \\
& Private & 41 & 24 \\
\hline University level & Yes & 58 & 33 \\
& No & 116 & 67 \\
\hline \multirow{2}{*}{ Administrative work experience } & Yes & 52 & 30 \\
& No & 122 & 70 \\
\hline STEM-related & Yes & 85 & 49 \\
& No & 89 & 51 \\
\hline
\end{tabular}

Note. $N=174$. STEM, science, technology, engineering, and mathematics. Average age of teachers is 38 years old. Average teaching experience is 12 years. 
For the individual qualitative interviews, eight volunteer teachers participated. The mean age of participants was 38 years old, while the average work experience was 12 years. Among the interview participants' seven were female, and one was male. All of the teachers worked in public (or national) elementary or high schools.

\subsection{Frequency and Preferences of TPD}

To understand the current status of TPD, the participants were asked to provide how often they participate in the various professional development activities. Table 2 show that the item "work with other teachers to ensure common standards in assessing student progress" was rated the highest with $\mathrm{M}=4.32(\mathrm{SD}=1.44)$, while the item "observe other teachers' classes and provide feedback" was rated the lowest with $\mathrm{M}=3.13(\mathrm{SD}=1.62)$. According to the results of the analysis, many of the high-scoring professional development activities revolve around student learning. The overall mean for the TPD frequency was calculated with $\mathrm{M}=3.85$ ( $\mathrm{SD}=1.23$ ), which means that the selected group of teachers take part in further professional development activities approximately five to ten times a year, which is considered quite good as compared to the results of TALIS 2018 [83].

Table 2. Item means for teacher professional development activities.

\begin{tabular}{|c|c|c|}
\hline Teacher Professional Development Activities & Mean & SD \\
\hline TPD-F01. Teach jointly as a team in the same class & 3.51 & 1.82 \\
\hline TPD-F02. Observe other teachers' classes and provide feedback & 3.13 & 1.62 \\
\hline TPD-F03. Engage in joint activities across different classes and age groups (e.g., research) & 3.45 & 1.56 \\
\hline TPD-F04. Exchange teaching materials with colleagues & 3.80 & 1.56 \\
\hline TPD-F05. Engage in discussions about the learning development of specific students & 4.25 & 1.44 \\
\hline TPD-F06. Work with other teachers to ensure common standards in assessing student progress & 4.32 & 1.44 \\
\hline TPD-F07. Attend team conferences, seminars, or workshops & 4.16 & 1.29 \\
\hline TPD-F08. Take part in collaborative professional learning & 4.17 & 1.40 \\
\hline Overall TPD frequency & 3.85 & 1.23 \\
\hline
\end{tabular}

Notes. $N=174$. SD, standard deviation. Cronbach's alpha reliability for TPD activities (frequency) $=0.92$.

For the TPD preferences, Table 3 showed that the most preferred professional development activities with the greatest positive impact on teaching were "it provided opportunities for active learning" with $\mathrm{M}=3.66(\mathrm{SD}=0.56)$, "it provided opportunities to practice/apply new teaching and knowledge in class" with $\mathrm{M}=3.64(\mathrm{SD}=0.55)$, and "it adapted to my personal development needs" with $\mathrm{M}=3.62(\mathrm{SD}=0.56$ ). While, the least preferred professional development activity was "it took place over an extended period of time (e.g., several weeks or longer)" with $\mathrm{M}=3.29$ (SD = 0.74). Despite the fact that this item was rated the least, the mean value is rated as moderately high on a four-point Likert scale. In addition, the results indicate that teachers preferred professional development activities that encourage active learning and collaboration [83].

Table 3. Item means for teacher professional development preferences.

\begin{tabular}{|c|c|c|}
\hline Teacher Professional Development Preferences & Mean & SD \\
\hline TPD-P01. It built on my prior knowledge & 3.60 & 0.58 \\
\hline TPD-P02. It adapted to my personal development needs & 3.62 & 0.56 \\
\hline TPD-P03. It had a coherent structure & 3.51 & 0.58 \\
\hline TPD-P04. It appropriately focused on the content needed to teach my subjects & 3.58 & 0.56 \\
\hline TPD-P05. It provided opportunities for active learning & 3.66 & 0.56 \\
\hline TPD-P06. It provided opportunities for collaborative learning & 3.59 & 0.61 \\
\hline TPD-P07. It provided opportunities to practice/apply new teaching and knowledge in class & 3.64 & 0.55 \\
\hline TPD-P08. It provided follow-up activities & 3.56 & 0.59 \\
\hline TPD-P09. It took place at my school & 3.36 & 0.67 \\
\hline TPD-P10. It involved most colleagues from my school & 3.43 & 0.67 \\
\hline TPD-P11. It took place over an extended period of time (e.g., several weeks or longer) & 3.29 & 0.74 \\
\hline TPD-P12. It focused on innovation in my teaching & 3.60 & 0.59 \\
\hline
\end{tabular}

Notes. $N=174$. SD, standard deviation. Cronbach's alpha reliability for TPD preferences $=0.96$. 


\subsection{Needs of and Barriers to TPD (Quantitative Results)}

For the TPD needs, a total of 21 items were combined from TALIS and several educational technology skills needed when teaching online during COVID-19 [39,64]. A number of criteria were considered in order to determine whether the items were factorable. To begin, correlations between items were examined with a minimum of 0.30 correlation between at least one other item, but no higher than 0.85 [84]. As a second step, several items were removed from the factor loadings due to cross-loading. Generally, primary loading should be at least 0.50 , and cross-loading should not exceed 0.32 [85]. Third, the Kaiser-Meyer-Olkin (KMO) measure of sampling adequacy was computed at 0.95 , well above the minimum cutoff value of 0.50 [86]. Fourth, Bartlett's test of sphericity was significant with $\chi^{2}(91)=2888.76, p<0.001$, signifying sampling adequacy [87]. Finally, communalities were calculated with all of the values over 0.40 , hence confirming that the items have some common variance [88].

After passing the initial assessment, a principal component analysis using the Varimax rotation was performed to identify the latent variables in the remaining 14 items [89]. The results showed that the remaining 14 items were successfully loaded into two variables that explain 80.36 percent of the total variance. In addition, confirmatory factor analysis using structural equation modeling results showed adequate model fit with SRMR $=0.031$, CMIN (73) $=157.71$ with $p<0.001, \mathrm{CMIN} / \mathrm{df}=2.16, \mathrm{RMSEA}=0.080(90 \% \mathrm{CI} 0.060$ and 0.099 ), GFI $=0.90, \mathrm{TLI}=0.97$, and CFI $=0.96$, wherein each of the criteria being within the prescribed limits.

Table 4 show the TPD needs variables and items displayed together with their mean, $\mathrm{SD}$, variance explained, communalities, and factor loadings that are all within the acceptable parameters. Two distinct variables are noted. Pedagogical needs are strategies that help develop teaching approaches that may affect learning, while information technology needs are the skills necessary to effectively use technology in online instruction. Several items were rated the highest within the pedagogical needs variables. For instance: "student behavior and classroom management" with $\mathrm{M}=3.75(\mathrm{SD}=0.53)$, "student assessment practices" with $\mathrm{M}=3.74$ (SD = 0.53), and "information technology skills for teaching" with $\mathrm{M}=3.74$ ( $\mathrm{SD}=0.52)$. While the item "teaching in a multicultural or multilingual setting" with $\mathrm{M}=3.61$ ( $\mathrm{SD}=0.62)$ was rated the lowest. For the information technology needs, "techniques on how to keep students engaged during online" was rated the highest with $\mathrm{M}=3.69$ (SD = 0.58). While "software for classroom or learning management systems" was rated the lowest with $\mathrm{M}=3.59$ ( $\mathrm{SD}=0.63)$. The overall mean of pedagogical needs is $\mathrm{M}=3.70(\mathrm{SD}=0.48)$, and information technology needs is $\mathrm{M}=3.62(\mathrm{SD}=0.56)$, both indicating moderately high perceived needs of teachers.

Table 4. Item means, communalities, and factor loadings for teacher professional development needs.

\begin{tabular}{|c|c|c|c|c|}
\hline Variables and Items (Variance Explained) & Mean & SD & Communalities & FL \\
\hline Pedagogical needs $(45.43 \%)$ & 3.70 & 0.48 & & \\
\hline TPD-N03. Knowledge of the curriculum & 3.72 & 0.53 & 0.74 & 0.75 \\
\hline TPD-N04. Student assessment practices & 3.74 & 0.53 & 0.83 & 0.83 \\
\hline TPD-N05. Information technology skills for teaching & 3.74 & 0.52 & 0.77 & 0.72 \\
\hline TPD-N06. Student behavior and classroom management & 3.75 & 0.53 & 0.82 & 0.82 \\
\hline TPD-N07. School management and administration & 3.71 & 0.58 & 0.79 & 0.80 \\
\hline TPD-N08. Approaches to individualized learning & 3.70 & 0.54 & 0.84 & 0.81 \\
\hline TPD-N09. Teaching students with special needs & 3.66 & 0.56 & 0.76 & 0.77 \\
\hline TPD-N10. Teaching in a multicultural or multilingual setting & 3.61 & 0.62 & 0.58 & 0.70 \\
\hline TPD-N12. Analysis and use of student assessments & 3.71 & 0.54 & 0.80 & 0.79 \\
\hline Information technology needs $(34.93 \%)$ & 3.62 & 0.56 & & \\
\hline TPD-N17. Using digital repositories or test banks to find resources & 3.62 & 0.60 & 0.82 & 0.80 \\
\hline TPD-N18. Digital tools for editing or develop new educational resources & 3.61 & 0.60 & 0.89 & 0.84 \\
\hline TPD-N19. Software for classroom or learning management systems & 3.59 & 0.63 & 0.90 & 0.89 \\
\hline TPD-N20. Digital evaluation tools to check students' learning & 3.61 & 0.62 & 0.87 & 0.83 \\
\hline TPD-N21. Techniques on how to keep students engaged during online & 3.69 & 0.58 & 0.85 & 0.78 \\
\hline
\end{tabular}

Notes. $N=174$. SD, standard deviation; FL, factor loading. Extraction method: principal component analysis. Rotation method: Varimax with Kaiser normalization. Rotation converged in 3 iterations. Cronbach's alpha reliability of overall TPD needs $=0.98$. 
For the TPD barriers, Table 5 show that the perceived greatest hurdle of professional development activities was "professional development is too expensive" with $\mathrm{M}=2.75$ $(\mathrm{SD}=0.95)$, while the least problematic was "there is no relevant professional development offered" with $\mathrm{M}=2.17$ ( $\mathrm{SD}=1.07)$. Overall TPD barriers were computed at $\mathrm{M}=2.41$ $(\mathrm{SD}=0.83)$, denoting moderate perceived obstacles to professional development activities.

Table 5. Item means for teacher professional development barriers.

\begin{tabular}{|c|c|c|}
\hline Teacher Professional Development Barriers & Mean & SD \\
\hline TPD-B01. I do not have the pre-requisites (e.g., qualifications, experience, seniority) & 2.41 & 1.02 \\
\hline TPD-B02. Professional development is too expensive & 2.75 & 0.95 \\
\hline TPD-B03. There is a lack of support from the school administration & 2.33 & 1.08 \\
\hline TPD-B04. Professional development conflicts with my work schedule & 2.56 & 0.93 \\
\hline TPD-B05. I do not have time because of family responsibilities & 2.33 & 0.97 \\
\hline TPD-B06. There is no relevant professional development offered & 2.17 & 1.07 \\
\hline TPD-B07. There are no incentives for participating in professional development & 2.29 & 1.08 \\
\hline Overall TPD barriers & 2.41 & 0.83 \\
\hline
\end{tabular}

Notes. $N=174$. SD = standard deviation. Cronbach's alpha reliability for TPD barriers $=0.92$.

\subsection{Intercorrelations}

Descriptive statistics, intercorrelations, reliabilities, and validities for the study variables are presented in Table 6. More specifically, the internal consistencies (alpha reliability values) are also provided together with the evidence for the validity (CR, AVE, DV, and HTMT) of the TPD needs variables (pedagogical and information technology needs); all of which are within the prescribed parameters. For the intercorrelations, besides the obvious positive correlations between age and teaching experience $(r=0.770, p<0.01)$, results showed that age and teaching experience were not correlated with any of the study variables, indicating that TPD needs, barriers, and frequencies are not dependent on age and experience. Interestingly, TPD frequency is positively correlated with pedagogical needs $(r=0.362, p<0.01)$ and information technology needs $(r=0.309, p<0.01)$, suggesting that the need for increased professional development of teachers could be met by more opportunities for professional development. Lastly, pedagogical needs and information technology needs are also positively correlated with each other $(r=0.813, p<0.01)$, implying that both needs go hand in hand and are closely related.

Table 6. Descriptive statistics, intercorrelations, reliabilities, and validities for the study variables.

\begin{tabular}{|c|c|c|c|c|c|c|c|c|}
\hline Variables & Mean & SD & 1 & 2 & 3 & 4 & 5 & 6 \\
\hline 1. Pedagogical needs & 3.70 & 0.48 & 0.96 & $0.813^{* *}$ & ns & $0.362 * *$ & ns & ns \\
\hline 2. Information technology needs & 3.62 & 0.56 & & 0.96 & ns & $0.309^{* *}$ & ns & ns \\
\hline 3. TPD barriers & 2.41 & 0.83 & & & 0.92 & ns & ns & $\mathrm{ns}$ \\
\hline 4. TPD frequency & 3.85 & 1.23 & & & & 0.92 & ns & ns \\
\hline 5. Age & 38.17 & 8.91 & & & & & & $0.770 * *$ \\
\hline 6. Teaching experience & 12.17 & 7.15 & & & & & & \\
\hline Minimum value & & & 1 & 1 & 1 & 1 & 22 & 1 \\
\hline Maximum value & & & 4 & 4 & 4 & 6 & 57 & 36 \\
\hline \multicolumn{3}{|c|}{ Composite reliability (CR) } & 0.962 & 0.960 & & & & \\
\hline \multicolumn{3}{|c|}{ Average variance extracted (AVE) } & 0.736 & 0.829 & & & & \\
\hline \multicolumn{3}{|c|}{ Discriminant validity (DV) ${ }^{1}$} & 0.858 & 0.910 & & & & \\
\hline \multicolumn{3}{|c|}{ Heterotrait-monotrait ratio of correlations (HTMT) } & \multicolumn{2}{|c|}{0.847} & & & & \\
\hline
\end{tabular}

Notes. $N=174$. Numbers 1 to 6 correspond to the variables. SD, standard deviation. Overall Cronbach alpha reliability of the survey $=0.86 .{ }^{1} \mathrm{DV}$ is computed using the squared root of AVE. Pearson correlation coefficients are above the diagonals. ns, non-significant and ${ }^{* *} p<0.01$. Internal consistency values: Cronbach's alpha coefficients are on diagonals. 


\subsection{Background Demographics and TPD}

To better understand the group differences with respect to the participants' background demographics, several independent samples t-tests were accomplished comparing gender (coded as binary with $0=$ female and $1=$ male), school type (coded as binary with $0=$ private and $1=$ public school), graduate degree, university level, administrative work experience (or duties), and STEM-related subject expertise (all coded in binary with $0=$ no and $1=$ yes).

Findings showed that there are no significant differences between gender, graduate education, and university teachers with regards to the TPD frequency, barriers, and needs. However, significant differences were found within the TPD frequencies of participants who have administrative work experience $(\mathrm{M}=4.15, \mathrm{SD}=1.18)$ and have no administrative work experience $(\mathrm{M}=3.72, \mathrm{SD}=1.23)$, with $t(172)=2.13, p<0.05$ and Cohen's $d$ [90] effect size of 0.36 . Similarly, significant differences were also found within the TPD frequencies of participants who taught STEM-related $(\mathrm{M}=4.08, \mathrm{SD}=1.21)$ and non-STEM related $(\mathrm{M}=3.63, \mathrm{SD}=1.21)$ subjects, with $t(172)=2.46, p<0.05$ and Cohen's $d$ effect size of 0.37 . These results suggest that higher occurrence of TPDs are observed among faculties that are also school administrators and also among faculties that taught STEM-related subjects. Lastly, significant differences were also found within the perceived TPD barriers for participants who are working in a public $(\mathrm{M}=2.48, \mathrm{SD}=0.82)$ and private $(\mathrm{M}=2.16$, $\mathrm{SD}=0.85$ ) institution, with $t(172)=2.23, p<0.05$ and Cohen's $d$ effect size of 0.38 . This means that private schools have a little more freedom in their TPD as compared to public schools. All of the effect sizes denoted medium effect [63].

\subsection{Needs of and Barriers to TPD (Qualitative Results)}

The qualitative results are distributed across the needs of and barriers to TPD. For the TPD needs, a total of 118 responses from the open-ended question in the survey were collected and analyzed together with the results from the individual interviews. Using Voyant tools, a total of 206 unique words were analyzed and organized together to form a keyword cloud (see Figure 1). Specifically, the most frequently used words by the respondents can be visualized in a graphical perspective (represented by decreasing font size, meaning the larger the text, the more frequent the word occurrence) [91,92]. The figure shows that teachers are primarily concerned with improving their teaching skills.

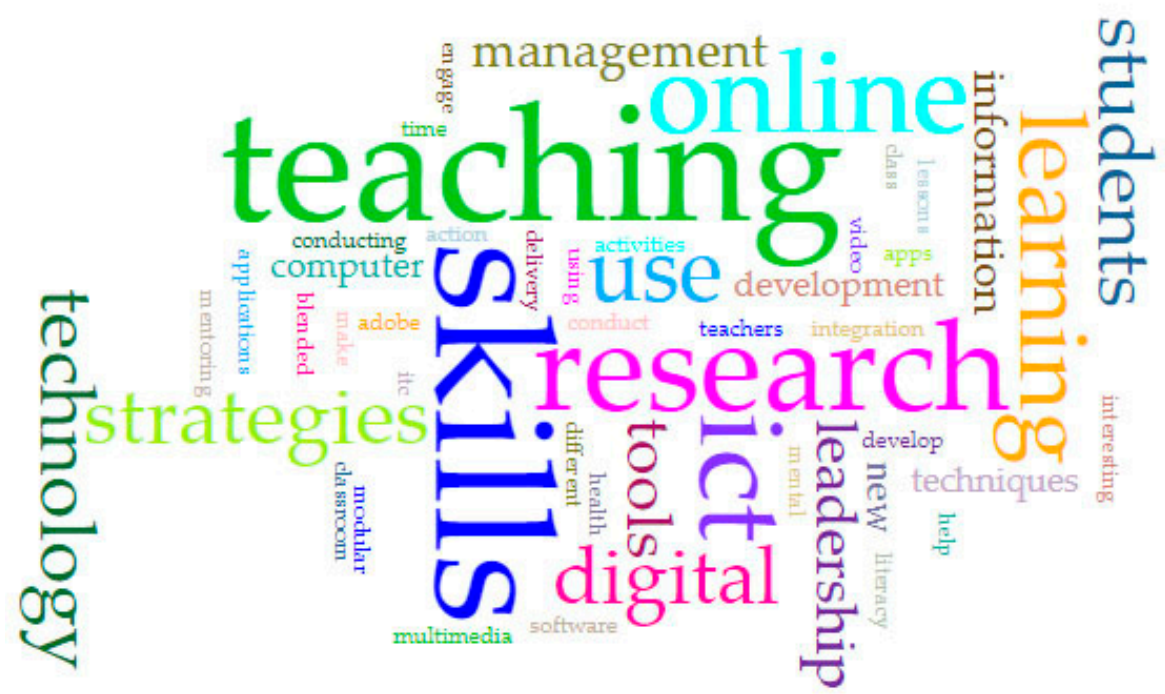

Figure 1. Keyword cloud for TPD needs.

In addition, some preliminary topics can be predicted, including online teaching skills, research skills, information and communication technology (ICT) (or digital) skills, and student learning. However, the keyword cloud should be interpreted with caution, as it does 
not reflect any collocations, common occurrences or possible variations in meaning [93]. It would be more accurate to highlight the connections between the frequently occurring words with a link or a collocates graph [81,94].

The five main keywords were also visualized. Figure 2 show the bubblelines and word trends to help visualize the frequency and distribution of the five main keywords [79,94]. The highest-ranking keywords are skills $(n=27)$, teaching $(n=24)$, ICT $(n=17)$, research $(n=16)$, and online $(n=14)$. In total, 98 instances were recorded. A trend chart for the five main keywords is also provided for clarity; showing the frequency of terms in the segments [95]. Findings indicate that several clusters (dashed circles) exist in which keywords occur in tandem, indicating underlying themes.

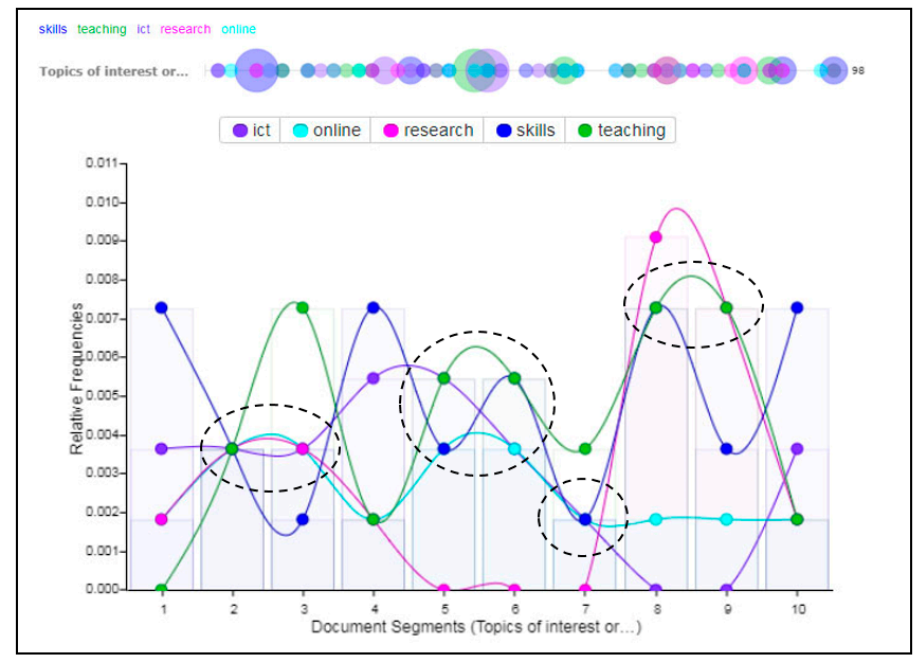

Figure 2. Graphical representation of the frequency of occurrence for the five main TPD needs.

In Figure 3, the five main TPD needs keywords are linked in a collocates graph. Linked keywords indicate how they are clustered together in the text (thicker lines signify higher occurrence), thus indicating underlying themes [96,97]. Findings suggest three emerging TPD needs together with some actual quotations from the individual interviews:

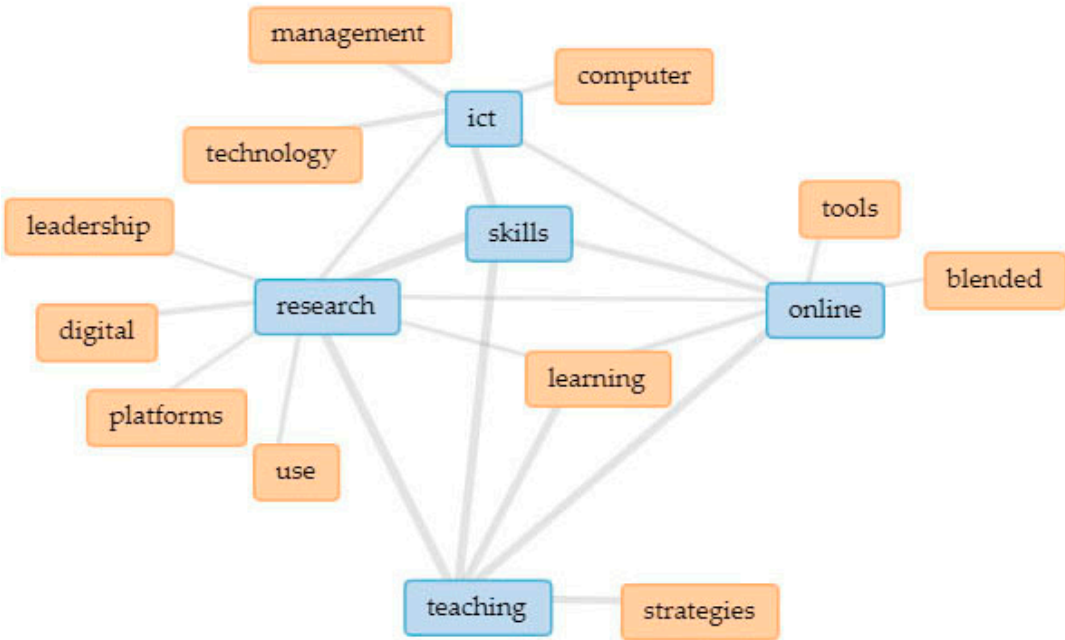

Figure 3. Interrelationships and extended links among the five main TPD needs.

Information technology skills or ICT skills-these are the digital skills that teachers need to help improve the teaching process, which might include but are not limited to the effective use of word processing software, spreadsheets, presentation software, social media, general multimedia skills, and knowledge of cloud storage and sharing [98-100]. 
What we need is more advanced skills on how to use Microsoft PowerPoint and the Adobe applications (Teacher 1 )

I saw on the internet that there are online learning management systems that are quite easy to use. It would be helpful if the school could assist me or teach me how to do it (Teacher 5)

I need to learn how to use programs or software that can let the students do online peer work or collaboration (Teacher 7)

Online teaching skills and strategies-COVID-19 requires teachers to learn more than just ICT skills; they should also learn how to innovate and create engaging online learning experiences for their students [101,102]. Moreover, teachers need to be familiar with the different modes of online teaching, whether it is synchronous, asynchronous, or blended learning [98,103].

... for me, video editing and how to effectively do blended teaching, here in our school, we are practicing 1-week synchronous and 1-week asynchronous instruction ... we need more effective teaching strategies (Teacher 3 )

Sometimes I feel my students are struggling, how can I motivate my students ... how can I maximize the use of technology in teaching ... (Teacher 5)

... I am teaching high school science. Some of my problems are how to teach laboratory skills using an online environment... I can look for YouTube videos, but I still felt this is not enough (Teacher 6)

How to effectively deliver science lessons using apps offline, I need to find some strategies that the students can use offline... (Teacher 2)

Research skills-in the Philippines, teachers have been instructed to include school-based action research in their performance appraisals and promotion in accordance with a recent mandate from the Department of Education and the Commission of Higher Education [104]. Furthermore, research skills may be beneficial for teachers who are also pursuing graduate degrees [105].

Since we are encouraged to take up graduate students ... how to do research in times of pandemic... (Teacher 1)

Just wondering, how can we integrate our action research and use the results afterwards ... we need to do research to better understand our students (Teacher 6)

A total of 108 answers from the open question of the survey were collected for the TPD barriers and evaluated together with the results from the individual interviews. Using a similar procedure, a total of 257 unique words were analyzed and combined into a keyword cloud (see Figure 4). According to the keyword cloud, financial support and time pressure are the two most important TPD barriers. This is then followed by problems with internet connections. 


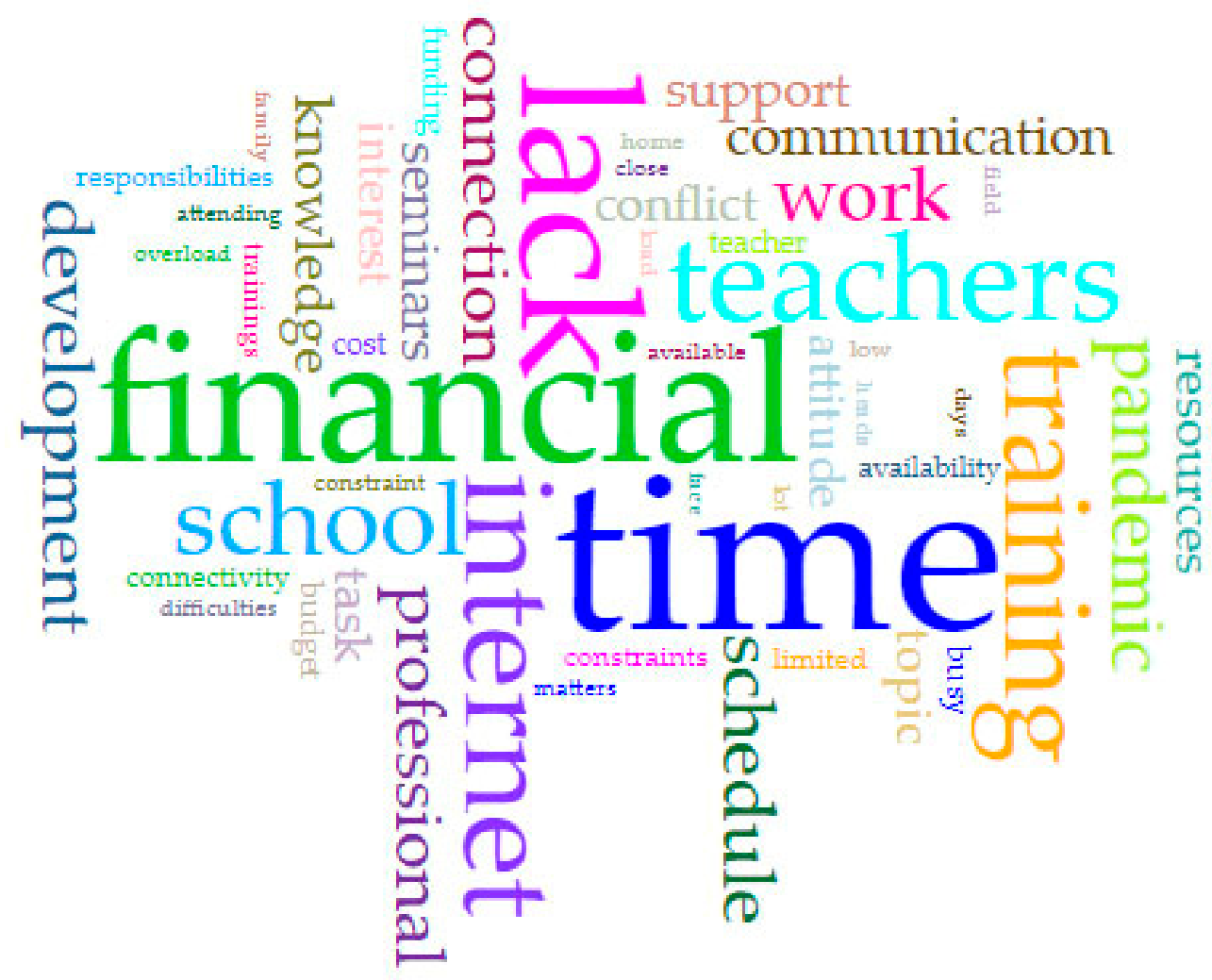

Figure 4. Keyword cloud for TPD barriers.

Figure 5 show the bubblelines and word trends of the top five high-frequency words with time $(n=22)$, financial $(n=17)$, lack $(n=14)$, internet $(n=10)$, and teachers $(n=9)$. In total, 72 instances were recorded with several clusters (dashed circles) in which keywords occur in tandem, indicating underlying themes.

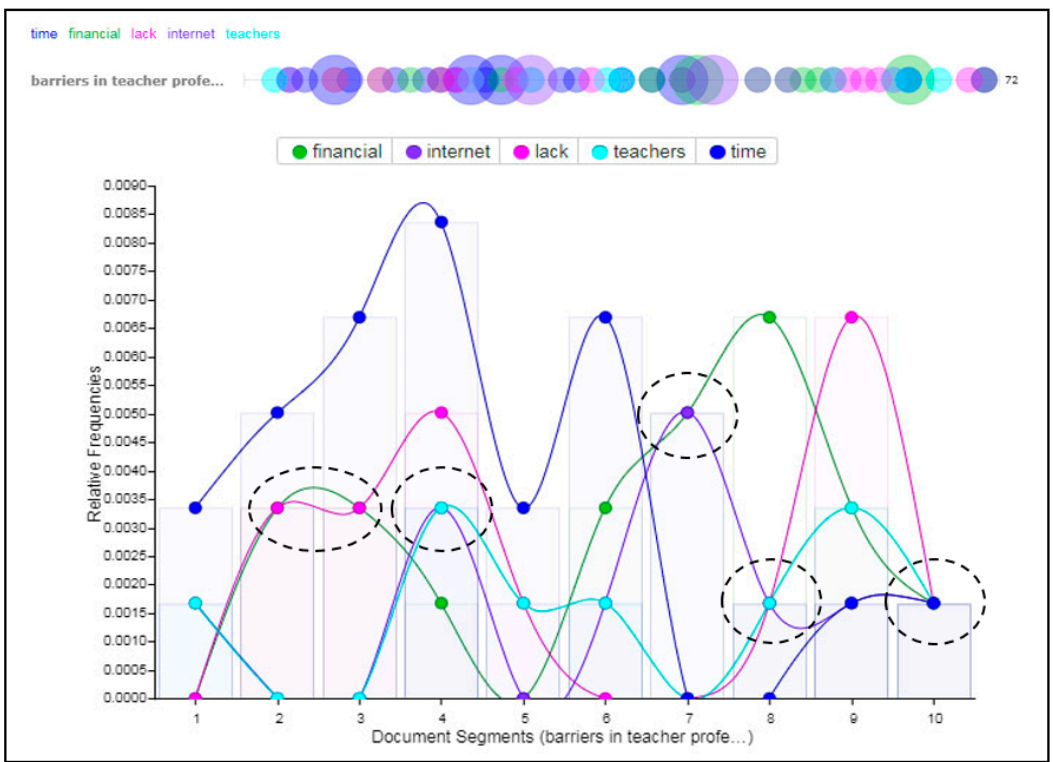

Figure 5. Graphical representation of the frequency of occurrence for the five main TPD barriers.

In Figure 6, the five main TPD barriers keywords are linked in a collocates graph. Clustering of keywords in the text is depicted by thicker lines (higher occurrence signifies more commonly occurring keywords), which suggests an underlying theme. 


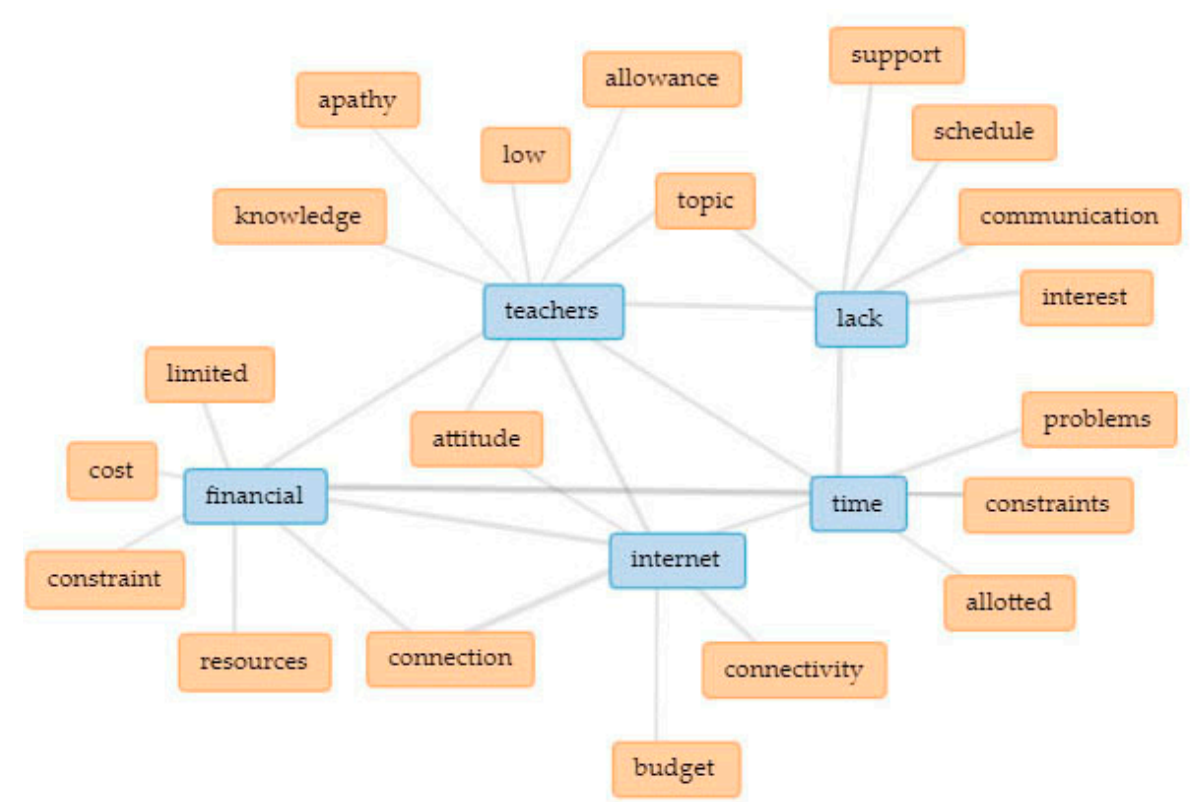

Figure 6. Interrelationships and extended links among the five main TPD barriers.

Findings suggest three emerging TPD barriers together with some actual quotations from the individual interviews:

Financial support and time constraints-approximately 20 percent of qualitative responses have noted the lack of funding and time off from work (including scheduling conflicts for TPD activities) as major barriers to participation.

There is always of problem in scheduling of professional developments ... training should be done before the opening of classes and not during when teachers are busy (Teacher 2) cost of professional development and busy schedule from school assignments are the most frequent reasons for non-participation of teachers (Teacher 8)

... cost of training is high and conflicts with my time and other responsibilities (Teacher 4)

Lack of teacher motivation and logistical support-these relate to the intrinsic motivations of teachers (might include teachers' lack of interest) and the lack of institutional supports.

... sometimes, the topic needed is not available and was not able to join due to conflict with work schedule (Teacher 4)

too overworked and taking part in professional development will be taking away our time to rest (Teacher 7)

Infrastructure problems-these are the problems related to unfavorable learning conditions and insufficient internet that plague both teachers and students in the Philippines [11].

internet signal and equipment or gadgets to be used for attending online workshops (Teacher 1)

difficult working conditions, systematic challenges, and poorly designed professional development, I believe these are the major concerns of a lot of teachers (Teacher 4)

\subsection{Relationship between TPD Needs and Preferences}

Hierarchical multiple regression analyses were conducted to reveal the significant role of TPD preferences in predicting TPD needs. Variables associated with TPD needs were entered using a three-step procedure. First, in order to control for possible effects of background demographic, age (in years), gender ( $0=$ female, $1=$ male), teaching experience (in years), and graduate degree $(0=$ no, $1=$ yes $)$, were entered into the equation as control 
variables. In the second step, work situations such as school type $(0=$ private, $1=$ public $)$, administrative work duties $(0=$ no, $1=$ yes $)$, university level $(0=$ no, $1=$ yes $)$, STEM-related $(0=$ no, $1=$ yes $)$, and TPD frequency, were entered into the equation. Lastly, the predictor variables, which are the various TPD preferences, were entered into the equation.

Table 7 display the results of the hierarchical multiple regression analyses. For the pedagogical needs, the work situations TPD frequency $(\beta=0.38, t(164)=5.11, p<0.001)$ increased the explained variance to 16.80 percent $(F[9,164]=3.69, p<0.001)$. While, the predictor variables TPD-P05 "it provided opportunities for active learning" ( $\beta=0.40$, $t(152)=2.17, p<0.05)$ and TPD-P07 "it provided opportunities to practice/apply new teaching and knowledge in class" $(\beta=-0.35, t(152)=-3.18, p<0.01)$ increased the explained variance to 63.90 percent $(F[21,152]=12.81, p<0.001)$.

Table 7. Hierarchical multiple regression analyses for predicting teacher professional development needs.

\begin{tabular}{|c|c|c|c|c|c|c|c|c|}
\hline & Predictors & F Change & $t$ & df & B & SE & $\beta$ & $\mathbf{R}^{2}$ Change \\
\hline \multicolumn{9}{|c|}{ A. Dependent variable: Pedagogical needs } \\
\hline \multirow[t]{6}{*}{ I. } & Constant & & & & 3.46 & 0.22 & & 0.027 \\
\hline & Control variables & 1.18 & & 4,169 & & & & \\
\hline & Age & & 1.24 & & 0.01 & 0.01 & 0.15 & \\
\hline & Gender & & 0.56 & & 0.04 & 0.08 & 0.04 & \\
\hline & Teaching experience & & -0.07 & & $<0.01$ & 0.01 & -0.01 & \\
\hline & Graduate degree & & -0.97 & & -0.10 & 0.10 & -0.08 & \\
\hline \multirow[t]{6}{*}{ II. } & Work situations & $3.69 * * *$ & & 9,164 & & & & 0.141 \\
\hline & School type & & 0.60 & & 0.05 & 0.08 & 0.04 & \\
\hline & Administrative duties & & -0.75 & & -0.06 & 0.08 & -0.06 & \\
\hline & University & & 1.08 & & 0.09 & 0.08 & 0.09 & \\
\hline & STEM & & -0.31 & & -0.02 & 0.07 & -0.02 & \\
\hline & TPD frequency & & $5.11^{* * *}$ & & 0.15 & 0.03 & 0.38 & \\
\hline \multirow[t]{13}{*}{ III. } & $\begin{array}{l}\text { Predictors } \\
\text { (preferences) }\end{array}$ & $12.81^{* * *}$ & & 21,152 & & & & 0.471 \\
\hline & TPD-P01 & & 0.76 & & 0.07 & 0.09 & 0.08 & \\
\hline & TPD-P02 & & -0.59 & & -0.05 & 0.09 & -0.06 & \\
\hline & TPD-P03 & & 1.57 & & 0.13 & 0.08 & 0.16 & \\
\hline & TPD-P04 & & 0.44 & & 0.04 & 0.09 & 0.05 & \\
\hline & TPD-P05 & & $2.17 *$ & & 0.34 & 0.16 & 0.40 & \\
\hline & TPD-P06 & & 1.23 & & 0.13 & 0.11 & 0.17 & \\
\hline & TPD-P07 & & $-3.18^{* *}$ & & -0.30 & 0.10 & -0.35 & \\
\hline & TPD-P08 & & 1.25 & & 0.11 & 0.09 & 0.14 & \\
\hline & TPD-P09 & & 0.41 & & 0.02 & 0.06 & 0.03 & \\
\hline & TPD-P10 & & 1.94 & & 0.12 & 0.06 & 0.16 & \\
\hline & TPD-P11 & & -1.80 & & -0.09 & 0.05 & -0.14 & \\
\hline & TPD-P12 & & 1.84 & & 0.14 & 0.08 & 0.18 & \\
\hline \multirow{7}{*}{ I. } & & B. Depender & ariable: In & nation $t$ & logy ne & & & \\
\hline & Constant & & & & 2.50 & 0.09 & & 0.010 \\
\hline & Control variables & 0.41 & & 4,169 & & & & \\
\hline & Age & & -0.03 & & $<0.01$ & 0.01 & $<0.01$ & \\
\hline & Gender & & -0.40 & & -0.04 & 0.09 & -0.03 & \\
\hline & Teaching experience & & 0.60 & & 0.01 & 0.01 & 0.08 & \\
\hline & Graduate degree & & -0.93 & & -0.11 & 0.12 & -0.08 & \\
\hline \multirow[t]{6}{*}{ II. } & Work situations & $2.20 *$ & & 9,164 & & & & 0.098 \\
\hline & School type & & -0.95 & & -0.10 & 0.10 & -0.07 & \\
\hline & Administrative duties & & -0.27 & & -0.03 & 0.09 & -0.02 & \\
\hline & University & & -0.06 & & -0.01 & 0.10 & -0.01 & \\
\hline & STEM & & 0.03 & & $<0.01$ & 0.09 & $<0.01$ & \\
\hline & TPD frequency & & $4.03^{* * *}$ & & 0.14 & 0.04 & 0.31 & \\
\hline
\end{tabular}


Table 7. Cont.

\begin{tabular}{|c|c|c|c|c|c|c|c|c|}
\hline & Predictors & F Change & $t$ & $\mathrm{df}$ & B & SE & $\beta$ & $R^{2}$ Change \\
\hline \multirow[t]{13}{*}{ III. } & $\begin{array}{c}\text { Predictors } \\
\text { (preferences) }\end{array}$ & $10.32^{* * *}$ & & 21,152 & & & & 0.480 \\
\hline & TPD-P01 & & -0.51 & & -0.06 & 0.11 & -0.06 & \\
\hline & TPD-P02 & & 1.70 & & 0.19 & 0.11 & 0.19 & \\
\hline & TPD-P03 & & 0.39 & & 0.04 & 0.11 & 0.04 & \\
\hline & TPD-P04 & & -0.39 & & -0.04 & 0.11 & -0.04 & \\
\hline & TPD-P05 & & 0.93 & & 0.18 & 0.20 & 0.18 & \\
\hline & TPD-P06 & & 1.63 & & 0.22 & 0.13 & 0.24 & \\
\hline & TPD-P07 & & -1.57 & & -0.19 & 0.12 & -0.18 & \\
\hline & TPD-P08 & & 0.19 & & 0.02 & 0.11 & 0.02 & \\
\hline & TPD-P09 & & $-2.01 *$ & & -0.14 & 0.07 & -0.17 & \\
\hline & TPD-P10 & & $4.26^{* * *}$ & & 0.33 & 0.08 & 0.39 & \\
\hline & TPD-P11 & & -1.80 & & -0.11 & 0.06 & -0.15 & \\
\hline & TPD-P12 & & $3.16^{* *}$ & & 0.31 & 0.10 & 0.32 & \\
\hline
\end{tabular}

Notes. $N=174, t$, for within-set predictors; $\mathrm{df}$, degrees of freedom; B, unstandardized coefficients; SE, standard error; $\beta$, standardized coefficients. Gender was coded as binary with 0 , female and 1, male. School type was coded as binary with 0 , private and 1, public school. Graduate degree, administrative duties, university, and STEM were all coded in binary with 0 , no, and 1 , yes. ${ }^{*} p<0.05,{ }^{* *} p<0.01$, and ${ }^{* * *} p<0.001$. For more details on the predictors (or TPD preferences), please refer to Table 3.

For the information technology needs, the work situations TPD frequency $(\beta=0.31$, $t(164)=4.03, p<0.001)$ increased the explained variance to 10.80 percent $(F[9,164]=2.20$, $p<0.05)$. While, the predictor variables TPD-P09 "it took place at my school" ( $\beta=-0.17$, $t(152)=-2.01, p<0.05)$, TPD-P10 "it involved most colleagues from my school" ( $\beta=0.39$, $t(152)=4.26, p<0.001)$, and TPD-P12 "it focused on innovation in my teaching" $(\beta=0.32$, $t(152)=3.16, p<0.01)$ increased the explained variance to 58.80 percent $(F[21,152]=10.32$, $p<0.001)$.

\section{Discussion}

\subsection{Quantitative Findings}

Statistically speaking, the selected group of Filipino teachers took part in further training measures five to ten times in the past year, which can be described as quite good in comparison to the TALIS results [83]. However, this situation may be linked to an increase in online teaching due to COVID-19, hence the sudden need for teacher training on online teaching tools and techniques [106-109]. During COVID-19, teachers face many challenges. In a virtual environment, teachers who have never taught before are expected to provide instructions that support students emotionally and socially and promote home-school connections [110].

In reality, the transition to online teaching during COVID-19 was experienced very differently by each faculty [111]. As teachers' fatigue and cynicism increased, they also saw their classroom management skills increase [112]. Additionally, experiencing the first time teaching (or working) from home, there are so much to consider, for instance: keeping a good work-life balance, disruptions at home, difficulties maintaining a personal connection with students, inability to read students' body language and distinguish their tones, and less control over students' attendance [113].

Importantly, teachers are quite concerned about the learning development of specific students and the establishment of common guidelines on students' assessments during online education. Due to the challenging learning environment and the unstable internet connections in the Philippines [5,11], it is quite difficult to tell how the students are actually learning $[9,10,114]$. Furthermore, teachers are simultaneously using various teaching modalities (synchronous, asynchronous, or blended learning) and technologies (Zoom, Google meet, Microsoft Teams, and many others) [115], students' performance would be extremely difficult to assess [116]. These issues are actually reflected in the current TPD findings, which are also in line with the recent research conducted on the subject. 
As for teachers' needs, quite high pedagogical and information technology needs indicate that during COVID-19, besides improving their information technology literacy, teachers are also focusing on improving their teaching techniques. Studies have shown that ICT skills development is best conducted early in teacher development [117]; however, during COVID-19, teachers could develop information technology literacy through the understanding of students' learning needs and actual online teaching practices [118]. Nonetheless, the successful delivery of online learning still depends on improving the teachers' technological pedagogical content knowledge $[98,119]$. In most cases, teachers are forced to become familiar with online instruction for the very first time. It is through their involvement in these online activities during COVID-19 that they will gain an understanding of what actually works.

Findings also showed that professional development is hindered by financial difficulties and scheduling conflicts. These are in line with the findings of TALIS 2018, wherein OECD teachers ranked "professional development conflicts with my work schedule" and "professional development is too expensive" among the toughest barriers to professional development [83]. Early studies noted various personal and organizational barriers to professional development [120]. Organizational or institutional barriers typically consist of finances, while personal motivations and the perceived benefits of professional development are some intrinsic factors [121,122]. Moreover, some institutions have cultures that either promote or hinder professional development [123]. Furthermore, teachers' lack of commitment, interest, and confidence are also important reasons for non-participation [124]. Likewise, the current group of teachers in the Philippines concurred with the major trends of obstacles to professional development.

With regards to the intercorrelations among the study variables, besides the obvious positive association between age and teaching experience, teachers were also found to be more interested in professional development when they have already participated in previous training. This is evident by the positive association between TPD frequency, and the two TPD needs variables (pedagogical and information technology needs). This finding actually coincides with early TALIS results, wherein half of the teachers reported that they needed more professional development in order to meet their needs [60]. Contrary to recent studies in the United States suggesting younger teachers prefer more professional development [125], for the current select group of Filipino teachers, no age difference seems to exist.

Additionally, it was evident from group comparisons that teachers working in private schools have more autonomy in their TPDs. Moreover, administrators and teachers within the STEM sector are more likely to participate in professional development activities. As noted, this latter finding is consistent with the current educational trends in the Philippines, where the focus has been placed on improving science and mathematics instruction [46,47]. Furthermore, school administrators are setting a good example by attending more TPDs, thereby encouraging their teachers to participate. This is a form of leadership by example where professional development can support the transformation from teachers to not only subject matter experts but also capable leaders in the future [126].

For the relationship between TPD needs and the different insights into the kinds of professional development content that enhance teaching (TPD preferences) [39], two multiple hierarchical regressions were accomplished. After controlling for the effects of background demographics and work situations, several interesting findings were noted. For the pedagogical needs, it would appear that within the present COVID-19 situation, most teachers prefer to stick to current materials rather than teaching new ones. This is understandable, especially since Filipino teachers were so stressed and busy dealing with the pandemic in the past school year [127]. Nonetheless, teachers must focus more on creating active and engaging lessons. In reality, because of the many distractions students experience while studying online at home, it is a difficult task to get students to engage and actively learn [128-130]. 
In relation to the need for information technology, teachers preferred online training and the participation of colleagues from their schools. In a recent study on TPD, it has been found that having a colleague (or co-teacher) that can either act as a mentor or companion is beneficial to the learning process [131]. This can be related to the teacher's help-seeking tendencies, which is one of the proponents of self-regulated learning [132]. In addition, teachers strive to make the teaching process more creative by using innovative teaching strategies. However, this can only be achieved through high-quality teacher preparation, adapting professional learning opportunities to current needs and providing supportive mentorship for teachers [19], which is the main purpose of having TPDs.

\subsection{Qualitative Findings}

To better understand and contextualize the quantitative results, the following section presents the qualitative findings that highlight the needs and barriers to TPD. Based on the teachers' responses, the findings suggest three emerging TPD need: information technology skills or ICT skills, online teaching skills and strategies, and research skills. Besides research skills, ICT and pedagogical skills are reflected in the quantitative findings of this study. It was actually surprising to see the inclusion of research skills within the qualitative results. This may be reflecting the recent move by the Department of Education for educators to be informed by credible research. The better-informed teachers are, the better they can make sound decisions about educational experiences and contribute to the improvement of schools and curriculums.

The unprecedented effects of the COVID-19 pandemic forced the education system to use ICT tools as an alternative to teaching the student community [133]. In some countries, ICT policies have started to be rethought and reshaped to provide teachers with the necessary training and framework for technology-related professional development [134]. Educational institutions should understand the changes in teaching and learning in this digital age. Training opportunities to support teacher needs on online or distance learning is vital and a priority.

Similar to the quantitative results of the TPD needs, the qualitative results also indicated that teachers need to update their online teaching skills and strategies related to ICT competencies. The pandemic has moved the teachers to adopt a digital mindset. It is a cultural shift that requires the use of the same tools and teaching strategies within the online context [135]. In online teaching, some strategies work best, while others are ineffective. Teachers feel inadequate and unprepared to use online platforms. A study of student perspectives on teachers' responses during the pandemics found that effective strategies, tools, and technologies include hybrid teaching that provides multiple resources and clear directions [136]. They perceive increasing workload, recorded lectures, inadequate communication, technical errors and outdated lecture formats as ineffective strategies. These valuable insights from the qualitative findings are important in training and updating online teaching skills and strategies for teachers.

The last emerging TPD need of teachers is research skills. As mandated by the Department of Education and the Commission of Higher Education in the Philippines, re-search is a requirement in performance appraisals and for the promotion of the teachers. Studies show that teachers lack a deep understanding and empirical evidence of how research-based education can support the teaching-learning process in schools and teacher development [137]. Hence, research skills, including knowledge and methodology, are needed to advance the understanding of teaching and learning processes in education. Moreover, the qualitative results of the study suggest three emerging TPD barriers among the teachers. These barriers are lack of financial support and time constraints, lack of teacher motivation and logistical support, and infrastructure problems, which agree with the initial quantitative findings.

The first emerging TPD barrier pertains to teachers' lack of financial support and time constraints. In the absence of compensation, teachers may not be able to cover their basic expenses. As a result, teachers may experience economic difficulties. Some studies report 
that a lack of financial support can increase teachers' feelings of stress and adversely impact children's learning experiences in the classroom $[138,139]$. Having less time to teach can also be associated with the effects of the lack of funding.

Lack of motivation and logistical support from teachers is the next emerging TPD barrier from the qualitative findings. Studies show that developing a supportive climate is one of the predictors of motivation $[140,141]$. Teachers tend to be highly motivated in institutions where administrative support is present. This support includes, but is not limited to, clear communication, training, reduced workload, social, financial, and logistical. Various insights were provided by these findings in conceptualizing teachers' needs, which are initially limited from a quantitative perspective.

Lastly, infrastructure issues such as unfavorable learning conditions and inadequate internet service pose barriers to teachers working remotely. In order to deliver quality education, it is imperative to understand the agencies that evolve in online learning. Online learning is characterized by accessibility to technology, infrastructure to conduct classes, and safe interaction between students and teachers [142]. In the absence of adequate access to these services, formal education will be quite limited during the COVID-19 pandemic.

\section{Conclusions}

COVID-19 continues to cause havoc throughout the world. It continues to have a significant impact in all areas of people's lives, including education. The presence of remote teaching and learning still remains to be an option in the Philippines; thus, educational institutions must ensure that their teachers are given adequate support. This is why continuous professional development is essential for providing quality education to students.

The purpose of this study was to determine what Filipino teachers need in order to facilitate teaching in the context of the online instruction that has resulted from the COVID-19 pandemic. It is clear from the teacher's training preferences that TPD activities have a positive impact on the classroom. The teaching profession and standards cannot be sustained without TPD initiatives. Importantly, the findings in both quantitative and qualitative data show that teachers need professional development to enhance their skills in ICT, online teaching strategies, and research. These areas are new to the majority of teachers because the transition from face-to-face to online teaching was unanticipated. Teachers had become accustomed to traditional classrooms; however, the pandemic changed everything. This inadequacy in skills makes them uncomfortable and stressed about giving quality education to their students.

Aside from the need for professional development, this study also identified barriers to such development. Findings noted the lack of support across both financial and logistical fronts that may have contributed to a decline in teacher motivation. Moreover, some students were also unable to access education due to unfavorable learning conditions and poor internet connectivity in some parts of the country. These factors have caused stress among teachers, which has negatively affected their performance. It should be noted that this is an initial report based on data from the National Capital Region for teachers engaging in online instruction and that it may not be representative of the entire country. This type of study should be expanded in the future to include other forms of teaching modalities and the inclusion of other mediating or moderating variables such as self-efficacy and teacher satisfaction. In spite of this, the authors recommend that educational institutions pay close attention to the needs and barriers of their faculty. This is in order to provide them with adequate professional support and development. Thus, enabling teachers and the educational community to provide quality education to their students by enriching their learning experiences as they prepare for a sustainable future.

Author Contributions: Conceptualization, J.M.-C.C., G.S.C., F.d.C. and T.-H.W.; data curation, G.S.C., F.d.C., T.-H.W., C.D.d.C., J.L.G. and S.M.T.; formal analysis, G.S.C., F.d.C., T.-H.W., C.D.d.C. and J.L.G.; funding acquisition, G.S.C., T.-H.W. and Y.-C.H.; investigation, G.S.C., F.d.C., T.-H.W. and Y.-C.H.; methodology, J.M.-C.C., G.S.C., F.d.C., T.-H.W., C.D.d.C. and J.L.G.; project administration, J.M.-C.C., 
F.d.C., C.D.d.C. and J.L.G.; resources, J.M.-C.C., G.S.C., F.d.C., T.-H.W., Y.-C.H., C.D.d.C., J.L.G. and S.M.T.; software, G.S.C. and T.-H.W.; supervision, J.M.-C.C.; validation, J.M.-C.C., G.S.C., F.d.C., T.-H.W., Y.-C.H., C.D.d.C., J.L.G. and S.M.T.; visualization, G.S.C. and T.-H.W.; writing-original draft, J.M.-C.C., G.S.C., F.d.C., T.-H.W., Y.-C.H., C.D.d.C., J.L.G. and S.M.T.; writing-review and editing, J.M.-C.C., G.S.C., F.d.C., T.-H.W., Y.-C.H., C.D.d.C., J.L.G. and S.M.T. All authors have agreed to the current version of the manuscript.

Funding: This research did not receive any external funding. The APC was funded in part by Fu Jen Catholic University, Taiwan.

Institutional Review Board Statement: The study was conducted in accordance with the Declaration of Helsinki. Information was collected in a recognized educational environment that offered opportunities for learning. In addition, the information collected is encoded in such a way that the subjects' identifiers cannot be determined directly or indirectly.

Informed Consent Statement: The participants were all informed about the study and agreed to participate.

Data Availability Statement: Data for the current study is available at https://doi.org/10.6084/m9 .figshare.16787467.v1 (accessed on 12 October 2021).

Acknowledgments: The authors would like to thank all the teachers who took time out and participated in the study.

Conflicts of Interest: The authors declare no conflict of interest.

\section{References}

1. Hernando-Malipot, M. PH Among 5 Countries with Schools Closed Since COVID-19 Pandemic-UNICEF. Available online: https:/ / mb.com.ph/2021/08/25/ph-among-5-countries-with-schools-closed-since-covid-19-pandemic-unicef/ (accessed on 12 October 2021).

2. Wieland, N.; Francia, M. Filipino Children Continue Missing Education Opportunities in Another Year of School Closure. Available online: https: / www.unicef.org/philippines/press-releases/filipino-children-continue-missing-education-opportunitiesanother-year-school (accessed on 11 December 2021).

3. Ancheta, R.F.; Ancheta, H.B. The new normal in education: A challenge to the private basic education institutions in the Philippines. Int. J. Educ. Manag. Dev. Stud. 2020, 1, 1-19. [CrossRef]

4. Palatino, M. Why are Schools Still Closed in the Philippines? Available online: https://thediplomat.com/2021/09/why-areschools-still-closed-in-the-philippines / (accessed on 12 October 2021).

5. Panganiban, G.L.; Madrigal, D.V. Grappling with the learning modules: Experience of public elementary pupils attending English written modular classes. Tech. Soc. Sci. J. 2021, 20, 263-274. [CrossRef]

6. Pawilen, G.T. What do kindergarten children need to know about COVID-19 pandemic? A supplementary curriculum for Filipino young children during the period of enhanced community quarantine. Asia-Pac. J. Res. Early Child. Educ. 2020, 14, 23-44.

7. de Guzman, C. The Philippines Still Hasn't Fully Reopened Its Schools Because of COVID-19. What Is this Doing to Children? Available online: https:/ / time.com/6124045/school-closures-covid-education-philippines/ (accessed on 11 December 2021).

8. Luz, J.M. 3 Case Studies: How Ready Are Philippine Schools for Distance Learning? Available online: https:/ /www.rappler. $\mathrm{com} /$ nation/ase-studies-how-ready-are-philippine-schools-for-distance-learning/ (accessed on 11 December 2021).

9. Dizon, N.H.; de Guzman, M.F.D.; Uy, L.F.; Ganaden, A.R. Education concerns in public secondary schools of Division of Zambales, Philippines: An education response to COVID 19 pandemic of 2020. EAS J. Humanit. Cult. Stud. 2021, 3, 51-60. [CrossRef]

10. Rotas, E.E.; Cahapay, M.B. Difficulties in remote learning: Voices of Philippine university students in the wake of COVID-19 crisis. Asian J. Distance Educ. 2020, 15, 147-158.

11. Barrot, J.S.; Llenares, I.I.; del Rosario, L.S. Students' online learning challenges during the pandemic and how they cope with them: The case of the Philippines. Educ. Inf. Technol. 2021, 26, 7321-7338. [CrossRef] [PubMed]

12. Cho, Y.; Kataoka, S.; Piza, S. Philippine Basic Education System: Strengthening Effective Learning During the COVID-19 Pandemic and Beyond; The World Bank: Washington, DC, USA, 2021.

13. Ancho, I.V.; Arrieta, G.S. Filipino teacher professional development in the new normal. Educ. Self Dev. 2021, 16, 25-43. [CrossRef]

14. Bautista, J. In-Person Classes Resume for Over 2000 Metro Manila Kids. Available online: https://newsinfo.inquirer.net/152419 2/in-person-classes-resume-for-over-2k-metro-kids (accessed on 11 December 2021).

15. Rita, J.; Ombay, G. NCR Starts Pilot Face-To-Face Classes Amid COVID-19 Pandemic. Available online: https://www. gmanetwork.com/news/topstories/metro/813449/ncr-starts-pilot-face-to-face-classes-amid-covid-19-pandemic/story/ (accessed on 11 December 2021).

16. Madarang, C.R.S. New Poll Says Unstable Internet Remains Top Challenge in Distance Learning. Available online: https: / /interaksyon.philstar.com/politics-issues/2021/06/03/193126/new-poll-says-unstable-internet-remain-top-challenge-indistance-learning/ (accessed on 11 December 2021). 
17. Cabalza, D. DepEd to Expand In-Person Classes. Available online: https://newsinfo.inquirer.net/1526390/deped-to-expand-inperson-classes (accessed on 11 December 2021).

18. Mocon-Ciriaco, C. DepEd Cautiously Opens In-Person Classes in Some NCR Schools Amid Omicron Threat. Available online: https://businessmirror.com.ph/2021/12/06/deped-cautiously-opens-in-person-classes-in-some-ncr-schools-amidomicron-threat/ (accessed on 11 December 2021).

19. Darling-Hammond, L.; Hyler, M.E. Preparing educators for the time of COVID ... and beyond. Eur. J. Teach. Educ. 2020, 43, 457-465. [CrossRef]

20. Lockee, B.B. Shifting digital, shifting context: (Re)considering teacher professional development for online and blended learning in the COVID-19 era. Educ. Technol. Res. Dev. 2021, 69, 17-20. [CrossRef]

21. Mielgo-Conde, I.; Seijas-Santos, S.; Grande-de-Prado, M. Review about online educational guidance during the COVID-19 pandemic. Educ. Sci. 2021, 11, 411. [CrossRef]

22. Schildkamp, K.; Wopereis, I.; Kat-De Jong, M.; Peet, A.; Hoetjes, I. Building blocks of instructor professional development for innovative ICT use during a pandemic. J. Prof. Cap. Community 2020, 5, 281-293. [CrossRef]

23. Avalos, B. Teacher professional development in teaching and teacher education over ten years. Teach. Teach. Educ. 2011, 27, 10-20. [CrossRef]

24. Marcelo, C. Professional development of teachers: Past and future. Sísifo Educ. Sci. J. 2009, 8, 5-20.

25. Marx, R.W.; Blumenfeld, P.C.; Krajcik, J.S.; Soloway, E. New technologies for teacher professional development. Teach. Teach. Educ. 1998, 14, 33-52. [CrossRef]

26. Dos Santos, L.M. The relationship between workforce sustainability, stress, and career decision: A study of kindergarten teachers during the COVID-19 pandemic. Sustainability 2021, 13, 11521. [CrossRef]

27. Liu, H.; Chu, W.; Fang, F.; Elyas, T. Examining the professional quality of experienced EFL teachers for their sustainable career trajectories in rural areas in China. Sustainability 2021, 13, 10054. [CrossRef]

28. Postholm, M.B. Teachers' professional development: A theoretical review. Educ. Res. 2012, 54, 405-429. [CrossRef]

29. Desimone, L.M. Improving impact studies of teachers' professional development: Toward better conceptualizations and measures. Educ. Res. 2009, 38, 181-199. [CrossRef]

30. Zhao, Y. Preparing globally competent teachers: A new imperative for teacher education. J. Teach. Educ. 2010, 61, 422-431. [CrossRef]

31. Creemers, B.; Kyriakides, L.; Antoniou, P. Teacher Professional Development for Improving Quality of Teaching; Springer: Dordrecht, The Netherlands, 2013.

32. Havea, P.H.; Mohanty, M. Professional development and sustainable development goals. In Quality Education; Leal Filho, W., Azul, A.M., Brandli, L., Özuyar, P.G., Wall, T., Eds.; Springer: Cham, Switzerland, 2020; pp. 1-12.

33. Laurie, R.; Nonoyama-Tarumi, Y.; Mckeown, R.; Hopkins, C. Contributions of education for sustainable development (ESD) to quality education: A synthesis of research. J. Educ. Sustain. Dev. 2016, 10, 226-242. [CrossRef]

34. McKeown, R.; Hopkins, C. Teacher Education and Education for Sustainable Development: Ending the DESD and Beginning the Gap; York University: Toronto, ON, Canada, 2014.

35. Luppi, E. Training to education for sustainable development through e-learning. Procedia Soc. Behav. Sci. 2011, 15, 3244-3251. [CrossRef]

36. Castro, M.P.; Gómez Zermeño, M.G. Challenge based learning: Innovative pedagogy for sustainability through e-learning in higher education. Sustainability 2020, 12, 4063. [CrossRef]

37. Azeiteiro, U.M.; Bacelar-Nicolau, P.; Caetano, F.J.P.; Caeiro, S. Education for sustainable development through e-learning in higher education: Experiences from Portugal. J. Clean. Prod. 2014, 106, 308-319. [CrossRef]

38. Diamond, S.; Irwin, B. Using e-learning for student sustainability literacy: Framework and review. Int. J. Sustain. High. Educ. 2013, 14, 338-348. [CrossRef]

39. Ainley, J.; Carstens, R. Teaching and Learning International Survey (TALIS) 2018 Conceptual Framezork; OECD Education Working Papers, No. 187; OECD: Paris, France, 2018.

40. Barrera-Pedemonte, F. High-Quality Teacher Professional Development and Classroom Teaching Practices; OECD Education Working Papers, No. 141; OECD: Paris, France, 2016.

41. Opfer, D. Conditions and Practices Associated with Teacher Professional Development and Its Impact on Instruction in TALIS 2013; OECD Education Working Papers No. 138; OECD: Paris, France, 2016.

42. Sellen, P. Teacher Workload and Professional Development in England's Secondary Schools: Insights from TALIS; Education Policy Institute: London, UK, 2016.

43. Zhang, L.; Carter, R.A., Jr.; Zhang, J.; Hunt, T.L.; Emerling, C.R.; Yang, S.; Xu, F. Teacher perceptions of effective professional development: Insights for design. Prof. Dev. Educ. 2021. [CrossRef]

44. Mabuan, R.A. MOOCs and MOOC camps for online teacher professional development: Experiences and perspectives from the Philippines. In Online Education for Teachers of English as a Global Language; Kang, H.-S., Shin, D.-s., Cimasko, T., Eds.; Routledge: New York, NY, USA, 2020; pp. 80-104.

45. World Bank Group. Developing a Proficient and Motivated Teacher Workforce in the Philippines; Philippines Education Note No. 3; World Bank: Washington, DC, USA, 2016. 
46. Bonghanoy, G.B.; Sagpang, A.P.; Alejan, R.A., Jr.; Rellon, L.R. Transformative professional development for mathematics teachers. J. Math. Educ. 2019, 10, 289-302. [CrossRef]

47. Bilbao, P.; Morano, L.N.; Barcenal, T.; Castellano, M.A.; Nichols, S.; Tippins, D.J. Changing traditions of science teacher professional development in the Philippines. In Professional Development of Science Teachers: Local Insights with Lessons from the Global Community; Fraser-Abder, P., Ed.; Routledge: New York, NY, USA, 2002; pp. 70-87.

48. Hunter, J.; Fitzgerald, T. STEAM games are good for learning in elementary schools: A study of teacher professional development in the Philippines. In Proceedings of Society for Information Technology E Teacher Education International Conference; Schmidt-Crawford, D., Ed.; Association for the Advancement of Computing in Education: Waynesville, NC, USA, 2020; pp. 514-520.

49. Zeegers, Y. Curriculum development for teacher education in the Southern Philippines: A simultaneous process of professional learning and syllabus enhancement. Int. J. Educ. Dev. 2012, 32, 207-213. [CrossRef]

50. Morales, M.P.E.; Mercado, F.M.; Palisoc, C.P.; Palomar, B.C.; Avilla, R.A.; Sarmiento, C.P.; Butron, B.R.; Ayuste, T.O.D. Teacher professional development program (TPDP) for teacher quality in STEAM education. Int. J. Res. Educ. Sci. 2021, 7, 188-206. [CrossRef]

51. Misra, P. MOOCs for teacher professional development: Reflections and suggested actions. Open Prax. 2018, 10, 67-77. [CrossRef]

52. Gutierez, S.B.; Kim, H.-B. Becoming teacher-researchers: Teachers' reflections on collaborative professional development. Educ. Res. 2017, 59, 444-459. [CrossRef]

53. Morales, M.P.E. Participatory action research (PAR) cum action research (AR) in teacher professional development: A literature review. Int. J. Res. Educ. Sci. 2016, 2, 156-165. [CrossRef]

54. Elipane, L.E. Introducing lesson study as a professional development model in the islands of the Philippines. Adv. Sci. Lett. 2017, 23, 1126-1129. [CrossRef]

55. Dawadi, S.; Shrestha, S.; Giri, R.A. Mixed-methods research: A discussion on its types, challenges, and criticisms. J. Pract. Stud. Educ. 2021, 2, 25-36. [CrossRef]

56. Creswell, J.W.; Clark, V.L.P. Designing and Conducting Mixed Methods Research, 3rd ed.; Sage: Thousand Oaks, CA, USA, 2017.

57. Stanley, M. Voluntary sampling design. Int. J. Adv. Res. Manag. Soc. Sci. 2015, 4, 185-200.

58. McLellan, E.; MacQueen, K.M.; Neidig, J.L. Beyond the qualitative interview: Data preparation and transcription. Field Methods 2003, 15, 63-84. [CrossRef]

59. Aslam, H.D. Analysis of professional development practices for school teachers in Pakistan: A comparative case study of public and private schools of Pakistan (Punjab). Int. J. Hum. Resour. Stud. 2013, 3, 311-326. [CrossRef]

60. OECD. Creating Effective Teaching and Learning Environments: First Results from TALIS; OECD: Paris, France, 2009.

61. Likert, R. A Technique for the Measurement of Attitudes; Columbia University Press: New York, NY, USA, 1932.

62. Cronbach, L.J. Coefficient alpha and the internal structure of tests. Psychometrika 1951, 16, 297-334. [CrossRef]

63. Cohen, L.; Manion, L.; Morrison, K. Research Method in Education, 6th ed.; Routledge: Abingdon, UK, 2007.

64. Perifanou, M.; Economides, A.A.; Tzafilkou, K. Teachers' digital skills readiness during COVID-19 pandemic. Int. J. Emerg. Technol. Learn. 2021, 16, 238-251. [CrossRef]

65. Graham, J.W. Missing data analysis: Making it work in the real world. Annu. Rev. Psychol. 2009, 60, 549-576. [CrossRef]

66. Madley-Dowd, P.; Hughes, R.; Tilling, K.; Heron, J. The proportion of missing data should not be used to guide decisions on multiple imputation. J. Clin. Epidemiol. 2019, 110, 63-73. [CrossRef]

67. Ho, R. Handbook of Univariate and Multivariate Data Analysis and Interpretation with IBM SPSS; Taylor and Francis: New York, NY, USA, 2006.

68. Fornell, C.; Larcker, D.F. Evaluating structural equation models with unobservable variables and measurement error. J. Mark. Res. 1981, 18, 39-50. [CrossRef]

69. Anderson, J.C.; Gerbing, D.W. Structural equation modeling in practice: A review and recommended two-step approach. Psychol. Bull. 1988, 103, 411-423. [CrossRef]

70. Bollen, K.A. Structural Equations with Latent Variables; Wiley-Interscience: New York, NY, USA, 1989.

71. Abma, I.L.; Rovers, M.; van der Wees, P.J. Appraising convergent validity of patient-reported outcome measures in systematic reviews: Constructing hypotheses and interpreting outcomes. BMC Res. Notes 2016, 9, 226. [CrossRef] [PubMed]

72. Hu, L.-T.; Bentler, P.M. Cutoff criteria for fit indexes in covariance structure analysis: Conventional criteria versus new alternatives Struct. Equ. Modeling A Multidiscip. J. 1999, 6, 1-55. [CrossRef]

73. Henseler, J.; Ringle, C.M.; Sarstedt, M. A new criterion for assessing discriminant validity in variance-based structural equation modeling. J. Acad. Mark. Sci. 2015, 43, 115-135. [CrossRef]

74. Byrne, B.M. Structural Equation Modeling with AMOS. Basic Concepts, Applications, and Programming, 2nd ed.; Taylor \& Francis: New York, NY, USA, 2010.

75. Lautenschlager, G.J.; Mendoza, J.L. A step-down hierarchical multiple regression analysis for examining hypotheses about test bias in prediction. Appl. Psychol. Meas. 1986, 10, 133-139. [CrossRef]

76. Petrocelli, J.V. Hierarchical multiple regression in counseling research: Common problems and possible remedies. Meas. Eval. Couns. Dev. 2003, 36, 9-22. [CrossRef]

77. Sinclair, S.; Rockwell, G. Voyant Tools. Available online: https://voyant-tools.org/ (accessed on 12 October 2021).

78. Cleary, P.; Garlock, K.; Novak, D.; Pullman, E.; Mann, S. Text mining 101: What you should know. Ser. Libr. 2017, 72, 156-159. [CrossRef] 
79. Given, L.M.; Willson, R. Information technology and the humanities scholar: Documenting digital research practices. J. Assoc. Inf. Sci. Technol. 2018, 69, 807-819. [CrossRef]

80. Inversini, A. Managing passengers' experience through mobile moments. J. Air Transp. Manag. 2017, 62, 78-81. [CrossRef]

81. Hendrigan, H. Mixing digital humanities and applied science librarianship: Using voyant tools to reveal word patterns in faculty research. Issues Sci. Technol. Librariansh. 2019. [CrossRef]

82. Llego, M.A. DepEd basic education statistics for school year 2019-2020. Available online: https://www.teacherph.com/depedbasic-education-statistics-school-year-2019-2020/ (accessed on 30 October 2021).

83. OECD. TALIS 2018 Results: Teachers and School Leaders as Lifelong Learners; OECD: Paris, France, $2019 ;$ Volume 1.

84. Kline, R.B. Principles and Practice of Structural Equation Modeling; Guilford Press: New York, NY, USA, 2011.

85. Costello, A.B.; Osborne, J.W. Best practices in exploratory factor analysis: Four recommendations for getting the most from your analysis. Pract. Assess. Res. Eval. 2005, 10, 1-9.

86. Kaiser, H.F. An index of factorial simplicity. Psychometrika 1974, 39, 31-36. [CrossRef]

87. Henson, R.K.; Roberts, J.K. Use of exploratory factor analysis in published research: Common errors and some comment on improved practice. Educ. Psychol. Meas. 2006, 66, 393-416. [CrossRef]

88. Worthington, R.L.; Whittaker, T.A. Scale development research: A content analysis and recommendations for best practices Couns. Psychol. 2006, 34, 806-838. [CrossRef]

89. Acal, C.; Aguilera, A.M.; Escabias, M. New modeling approaches based on varimax rotation of functional principal components. Mathematics 2020, 8, 2085. [CrossRef]

90. Cohen, J. Statistical Power Analysis for the Behavioral Sciences, 2nd ed.; Lawrence Erlbaum Associates: Hillsdale, MI, USA, 1988.

91. Rose, J.; Lennerholt, C. Low cost text mining as a strategy for qualitative researchers. Electron. J. Bus. Res. Methods 2017, 15, 2-16.

92. Spaska, A.M.; Savishchenko, V.M.; Komar, O.A.; Hritchenko, T.Y.; Maidanyk, O.V. Enhancing analytical thinking in tertiary students using debates. Eur. J. Educ. Res. 2021, 10, 879-889. [CrossRef]

93. Hetenyi, G.; Lengyel, A.; Szilasi, M. Quantitative analysis of qualitative data: Using voyant tools to investigate the sales-marketing interface. J. Ind. Eng. Manag. 2019, 12, 393-404. [CrossRef]

94. Alhudithi, E. Review of voyant tools: See through your text. Lang. Learn. Technol. 2021, 25, 43-50.

95. Miller, A. Text mining digital humanities projects: Assessing content analysis capabilities of voyant tools. J. Web Librariansh. 2018, 12, 169-197. [CrossRef]

96. Manggong, L.; Riza, M.N. Postcolonial network analysis of Joseph Conrad's heart of darkness. In Proceedings of the 3rd English Language and Literature International Conference, Semarang, Indonesia, 27 April 2019; pp. $270-278$.

97. Mukwena, M. Words matter: Content analysis of higher education mission statements in Zambia. Int. J. Res. Educ. Humanit. Commer. 2020, 1, 1-12.

98. Ching, G.S.; Roberts, A. Evaluating the pedagogy of technology integrated teaching and learning: An overview. Int. J. Res. Stud. Educ. 2020, 9, 37-50. [CrossRef]

99. Wu, J.-F.; Ching, G.S. A study on the elementary school teachers' information technology literacy and teaching beliefs in Taiwan. In Proceedings of SITE Interactive 2020 Online Conference; Langran, E., Ed.; Association for the Advancement of Computing in Education: Waynesville, NC, USA, 2020; pp. 323-329.

100. Hakkarainen, K.; Muukonen, H.; Lipponen, L.; Liisallomäki, L.; Rahikainen, M.; Lehtinen, E. Teachers' information and communication technology (ICT) skills and practices of using ICT. J. Technol. Teach. Educ. 2001, 9, 181-197.

101. OECD. Teaching in Focus \#35: Teachers' Training and Use of Information and Communications Technology in the Face of the COVID-19 Crisis; OECD: Paris, France, 2020.

102. Peno, K. Developing online teaching skills: A self-directed approach. New Dir. Adult Contin. Educ. 2021, 2021, 101-110. [CrossRef]

103. Cahapay, M.B.; Anoba, J.L.D. The readiness of teachers on blended learning transition for post COVID-19 period: An assessment using parallel mixed method. PUPIL Int. J. Teach. Educ. Learn. 2020, 4, 295-316. [CrossRef]

104. Ulla, M.B.; Barrera, K.I.B.; Acompanado, M.M. Philippine classroom teachers as researchers: Teachers' perceptions, motivations, and challenges. Aust. J. Teach. Educ. 2017, 42, 52-64. [CrossRef]

105. David, A.P.; Reyes, Z.Q.; Miranda, P.A.; Nalipay, M.J.N.; Ancho, I.V.; Roxas, M.M. Graduate teacher education in the Philippines: Observations and prospects. Norm. Lights 2020, 14, 248-271.

106. Torres Martín, C.; Acal, C.; El Homrani, M.; Mingorance Estrada, Á.C. Impact on the virtual learning environment due to COVID-19. Sustainability 2021, 13, 582. [CrossRef]

107. Onyema, E.M.; Eucheria, N.C.; Obafemi, F.A.; Sen, S.; Atonye, F.G.; Sharma, A.; Alsayed, A.O. Impact of coronavirus pandemic on education. J. Educ. Pract. 2020, 11, 108-121.

108. Arnilla, A.K. Coaching teachers remotely during COVID-19 pandemic: Perspectives and experiences from a developing country. In Proceedings of the AUBH E-Learning Conference 2021: Innovative Learning \& Teaching-Lessons from COVID-19, Manama, Bahrain, 24-26 May 2021. [CrossRef]

109. Wang, X.-Y.; Li, G.; Malik, S.; Anwar, A. Impact of COVID-19 on achieving the goal of sustainable development: E-learning and educational productivity. Econ. Res. 2021. [CrossRef]

110. Vaughan, M.; Mertler, C.A. Reorienting our thinking away from 'professional development for educators' and toward the 'development of professional educators'. J. Sch. Leadersh. 2020. [CrossRef] 
111. Daumiller, M.; Rinas, R.; Hein, J.; Janke, S.; Dickhäuser, O.; Dresel, M. Shifting from face-to-face to online teaching during COVID-19: The role of university faculty achievement goals for attitudes towards this sudden change, and their relevance for burnout/engagement and student evaluations of teaching quality. Comput. Hum. Behav. 2021, 118, 106677. [CrossRef]

112. Sokal, L.; Trudel, L.E.; Babb, J. Canadian teachers' attitudes toward change, efficacy, and burnout during the COVID-19 pandemic. Int. J. Educ. Res. Open 2020, 1, 100016. [CrossRef]

113. Arora, R.G.; Chauhan, A. Faculty perspectives on work from home: Teaching efficacy, constraints and challenges during COVID' 19 lockdown. J. Stat. Manag. Syst. 2021, 24, 37-52. [CrossRef]

114. Means, B.; Neisler, J. Teaching and learning in the time of COVID: The student perspective. Online Learn. 2021, 25, 8-27. [CrossRef]

115. Ahshan, R. A framework of implementing strategies for active student engagement in remote/online teaching and learning during the COVID-19 pandemic. Educ. Sci. 2021, 11, 483. [CrossRef]

116. Bryant, J.; Chen, L.-K.; Dorn, E.; Hall, S. School-System Priorities in the Age of Coronavirus; McKinsey \& Company: Washington, DC, USA, 2020

117. List, A. Defining digital literacy development: An examination of pre-service teachers' beliefs. Comput. Educ. 2019, 138, 146-158. [CrossRef]

118. Gao, L.X.; Zhang, L.J. Teacher learning in difficult times: Examining foreign language teachers' cognitions about online teaching to tide over COVID-19. Front. Psychol. 2020, 11, 549653. [CrossRef]

119. Bragg, L.A.; Walsh, C.; Heyeres, M. Successful design and delivery of online professional development for teachers: A systematic review of the literature. Comput. Educ. 2021, 166, 104158. [CrossRef]

120. Stenfors-Hayes, T.; Weurlander, M.; Dahlgren, L.O.; Hult, H. Medical teachers' professional development-Perceived barriers and opportunities. Teach. High. Educ. 2010, 15, 399-408. [CrossRef]

121. Kennedy, A. Collaborative continuing professional development (CPD) for teachers in Scotland: Aspirations, opportunities and barriers. Eur. J. Teach. Educ. 2011, 34, 25-41. [CrossRef]

122. Abdollahi, B.; Safari, A. The study of key barriers to the teachers' professional development. Q. J. Educ. Innov. 2016, 15, 99-134.

123. Johnson, C.C. Effective professional development and change in practice: Barriers science teachers encounter and implications for reform. Sch. Sci. Math. 2006, 106, 150-161. [CrossRef]

124. Caffarella, R.S.; Zinn, L.F. Professional development for faculty: A conceptual framework of barriers and supports. Innov. High. Educ. 1999, 23, 241-254. [CrossRef]

125. Zhang, S.; Shi, Q.; Lin, E. Professional development needs, support, and barriers: TALIS US new and veteran teachers' perspectives. Prof. Dev. Educ. 2020, 46, 440-453. [CrossRef]

126. Taylor, M.; Yates, A.; Meyer, L.H.; Kinsella, P. Teacher professional leadership in support of teacher professional development. Teach. Teach. Educ. 2011, 27, 85-94. [CrossRef]

127. Talidong, K.J.B.; Toquero, C.M.D. Philippine teachers' practices to deal with anxiety amid COVID-19. J. Loss Trauma 2020, 25, 573-579. [CrossRef]

128. Brown, W.S. Successful strategies to engage students in a COVID-19 environment. Front. Commun. 2021, 6, 641865. [CrossRef]

129. Domina, T.; Renzulli, L.; Murray, B.; Garza, A.N.; Perez, L. Remote or removed: Predicting successful engagement with online learning during COVID-19. Socius Sociol. Res. A Dyn. World 2021. [CrossRef]

130. Minkos, M.L.; Gelbar, N.W. Considerations for educators in supporting student learning in the midst of COVID-19. Psychol. Sch. 2020, 58, 416-426. [CrossRef]

131. Ramírez-Montoya, M.S.; Andrade-Vargas, L.; Rivera-Rogel, D.; Portuguez-Castro, M. Trends for the future of education programs for professional development. Sustainability 2021, 13, 7244. [CrossRef]

132. Karabenick, S.A.; Gonida, E.N. Academic help seeking as a self-regulated learning strategy: Current issues, future directions. In Handbook of Self-Regulation of Learning and Performance; Schunk, D.H., Greene, J.A., Eds.; Routledge: Abingdon, UK, 2018; pp. 421-433.

133. Irrinki, M.K. Learning through ICT: Role of Indian higher education platforms during pandemic. Library Philosophy and Practice, 4 June 2021; p. 5254.

134. Choi, H.; Chung, S.-Y.; Ko, J. Rethinking teacher education policy in ICT: Lessons from emergency remote teaching (ERT) during the COVID-19 pandemic period in Korea. Sustainability 2021, 13, 5480. [CrossRef]

135. Stewart, C.; Khan, A.A. A strategy for using digital mindsets and knowledge technologies to move past pandemic conditions. Account. Res. J. 2021, 34, 345-356. [CrossRef]

136. Pagoto, S.; Lewis, K.A.; Groshon, L.; Palmer, L.; Waring, M.E.; Workman, D.; De Luna, N.; Brown, N.P. STEM undergraduates' perspectives of instructor and university responses to the COVID-19 pandemic in Spring 2020. PLoS ONE 2021, 16, e0256213. [CrossRef] [PubMed]

137. Heikkilä, M.; Hermansen, H.; Iiskala, T.; Mikkilä-Erdmann, M. Epistemic agency in student teachers' engagement with research skills. Teach. High. Educ. 2020, 1-18. [CrossRef]

138. King, E.K.; Johnson, A.V.; Cassidy, D.J.; Wang, Y.C.; Lower, J.K.; Kintner-Duffy, V.L. Preschool teachers' financial well-being and work time supports: Associations with children's emotional expressions and behaviors in classrooms. Early Child. Educ. J. 2016, 44, 545-553. [CrossRef] 
139. Li Grining, C.; Raver, C.C.; Champion, K.; Sardin, L.; Metzger, M.; Jones, S.M. Understanding and improving classroom emotional climate and behavior management in the "real world": The role of Head Start teachers' psychosocial stressors. Early Educ. Dev. 2010, 21, 65-94. [CrossRef]

140. Lin, Y.-Y. Support matters: Predictors of intrinsic motivation in older learners in Taiwan. Aust. J. Adult Learn. 2020, 60, 190-212.

141. Chappell, C.; Hawke, G.; Rhodes, C.; Solomon, N. Major Research Program for Older Workers—Stage 1: The Conceptual Framework; OVAL Research: Sydney, Australia, 2003.

142. Kamble, A.; Gauba, R.; Desai, S.; Golhar, D. Learners' perception of the transition to instructor-led online learning environments: Facilitators and barriers during the COVID-19 pandemic. Int. Rev. Res. Open Distrib. Learn. 2021, 22, 199-215. [CrossRef] 